\title{
Benthic foraminifera and calcareous algae from the Anisian-Norian succession in the Tatras (Poland and Slovakia): New data from High-Tatric and Krížna units
}

\author{
Tomasz RYCHLIŃSKI ${ }^{*}$, Daria K. IVANOVA², Piotr JAGLARZ ${ }^{1} \&$ Ioan I. BUCUR ${ }^{3}$ \\ ${ }^{1}$ Institute of Geological Sciences, Jagiellonian University, Oleandry Str. 2a, 30-063 Kraków, Poland \\ ${ }^{2}$ Geological Institute, Bulgarian Academy of Sciences, Acad. G. Bonchev Str., B1. 24, 1113 Sofia, Bulgaria \\ ${ }^{3}$ Department of Geology, Babeş-Bolyai University, Kogălniceanu 1, 400084 Cluj-Napoca, Romania
}

Received: September 2012; accepted January 2013

Available online 25 February 2013

DOI: http://dx.doi.org/10.5038/1937-8602.58.1.3

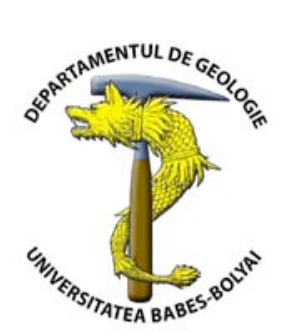

\begin{abstract}
The paper is focused on new micropalaeontological data from the Triassic succession of Krížna and High-Tatric units in the Tatra Mts. Benthic foraminifera species were determined from the Anisian-Norian succession of the Krížna Unit and the Anisian succession of the High-Tatric Unit. In the later, calcareous algae species were also found. In mentioned Triassic successions, most of genera were described for the first time, while the others were found in new locations. A few of them belong to index fossils. Based on the assemblage containing calcareous algae Oligoporella species, characteristic for the Oligoporella pilosa-Phisoporella panciforata zone, as well as the foraminifera Meandrospira dinarica, and the presence of Diplopora annulatissima, the age of the upper part of the Stoły pod Ciemniakiem section (High-Tatric Unit) is most probably Lower Illyrian. The establishment of the foraminifera species Pilamminella semiplana, Glomospirella triphonensis and Nodosaria skyphica, within the limestone of the Łysanki section and accompanying species Ophthalmidium cf. exiguum, Hoyenella gr. sinensis, Agathammina sp. and Gaudryina sp. from Żleb pod Czerwieniec and Skoruśniak sections (Krížna Unit): suggest early Anisian age. Ladinian age is indicated by the Turriglomina mesotriasica - Glomospirella kuthani/ gemerica - Aulotortus gaschei praegaschei assemblage present in the dolostones of the Skupniów Upłaz and Hlúpy sections (Krížna Unit). The assemblage from dolostones of the Żleb pod Czerwoną Przełęcz (Krížna Unit) includes ? Triasina hantkeni species, which is a zone marker for the upper Norian (Sevatian) to Rhaetian succession.
\end{abstract}

Keywords: foraminifera, algae, stratigraphy, Triassic, Tatricum, Fatricum, Western Carpathians

\section{INTRODUCTION}

The paper is focused on new micropalaeontological data from several sections of the Anisian-Norian succession of Krížna and High-Tatric units in the Tatra Mts (southern Poland, northern Slovakia). A few hundred metres complex of sedimentary rocks mentioned above contain rare index fossils. Genera described below belong to benthic foraminifera and calcareous algae. Some of described taxa are reported for the first time from mentioned succesion, whereas the others are found in further locations.

Presented data are a supplement of earlier investigations on benthic foraminifers and calcareous algae from Triassic of Krížna and High-Tatric units in the Tatra Mountains (Kotański, 1963, 1967, 1979a; Bac and Grochocka, 1965; Piotrowski, 1965; Bełka and Gaździcki, 1976; Gaździcki and Lipiec, 1995). Some of the identified taxa enable better biostratigraphical resolution of mentioned deposits.

\section{GEOLOGICAL SETTING}

The Tatra Mts are composed of the Variscan crystalline basement, its sedimentary cover and overthrusted nappes built of Mesozoic rocks (Fig. 1). High-Tatric Unit consists of autochthonous (or paraautochthonous) cover of crystalline rocks and two allochthonous units (the lower Czerwone Wierchy nappe and the upper Giewont nappe; Kotański, 1961, 1979b; Passendorfer, 1961; Dumont et al., 1996). High-Tatric Unit is overlaid by two Sub-Tatric nappes: the lower Krížna nappe and the upper Choč nappe. The Krížna nappe is composed of several partial nappes and tectonic scales (Goetel and Sokołowski, 1929; Sokołowski, 1948; Andrusov, 1959; Guzik and Kotański, 1963; Kotański, 1963; Bac, 1971).

Deposits of High-Tatric, Krížna and Choč were cumulated in Tatricum, Fatricum and Hronicum basins respectively (Andrusov et al., 1973; Kotański, 1979b; Michalík and Gaździcki, 1980).

The tectonic units are built of sedimentary rocks of Lower Triassic-Lower Turonian (High-Tatric Unit), Lower TriassicAlbian (Krížna Unit) and Middle Triassic to Bajocian (Choč Unit; Wieczorek, 2000; Uchman, 2004).

During Triassic time, Tatricum and Fatricum basins were located in the northern part of Carpathian branch of Western Tethys Ocean (Meliata-Hallstatt Ocean; Kozur, 1991; Michalík, 1994; Wieczorek, 2000). The palaeogeographical vicinity of both basins caused similar facies development during Triassic time. Diversification of sedimentary environments took place only in the Rhaetian as a result of tectonic disintegration of southern Palaeoeuropean shelf (Michalík, 1993, 1994). 


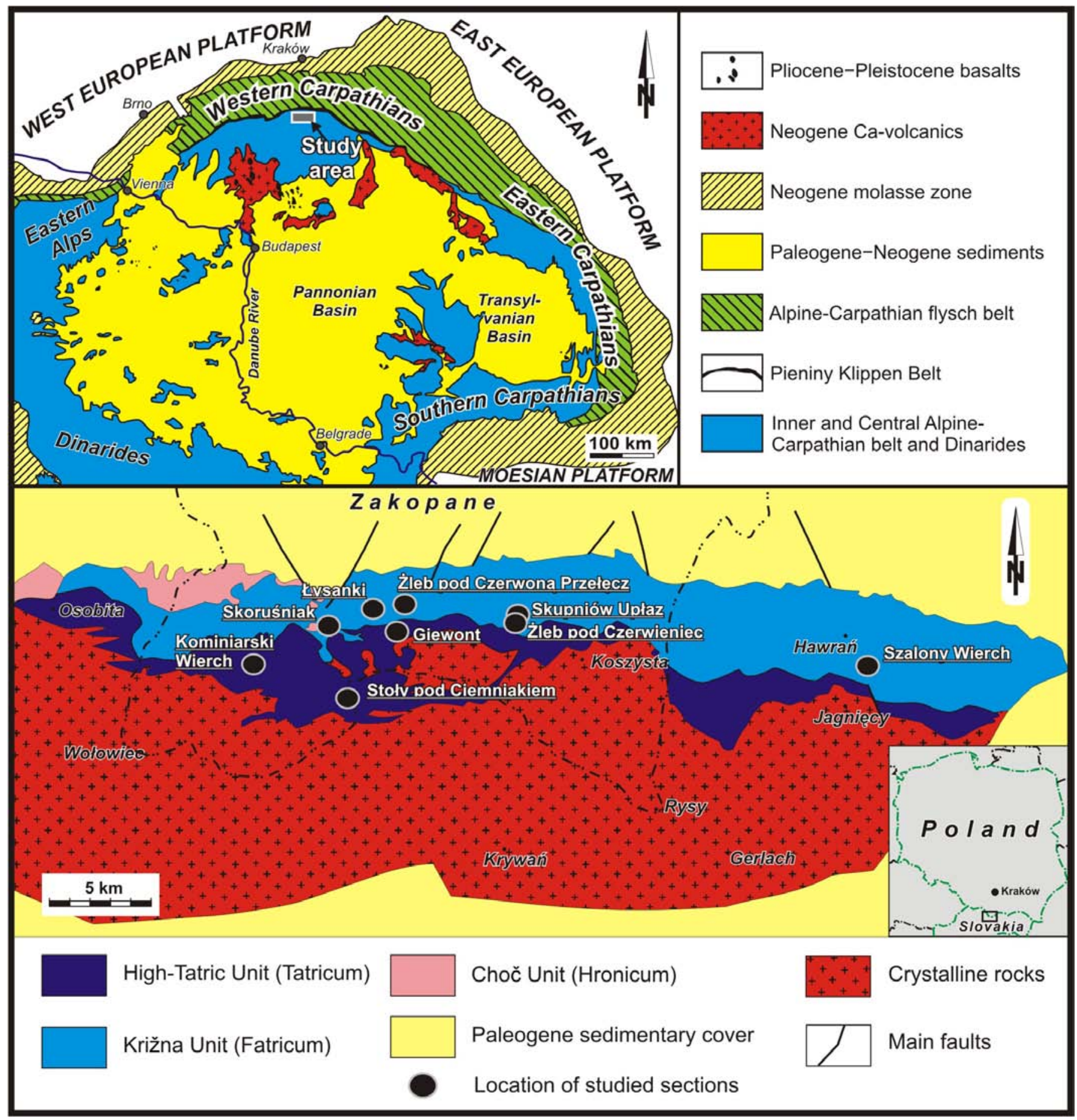

Fig. 1. Location of the study area. a) Location of the Tatra Mountains in the geological sketch-map of the Alpine-Carpathian-Pannonian orogenic belt (after Jurewicz, 2005; modified; b) Location of the studied sections in the tectonic sketch map of the Tatra Mountains (after Bac-Moszaszwili et al., 1979; modified).

Middle Triassic successions of Tatricum and Fatricum units are underlied by the upper Olenekian (Campilian) dolostones alternately with dark marly limestones (partly dedolostones) and dolomitic mudstones of Myophoria beds (Kotański, 1956a, 1963; Jaglarz and Rychliński, 2010). The above mentioned series represent hypersaline deposits of marginal zone of restricted carbonate ramp (Kotański, 1979a; Rychliński and Jaglarz, 2010). Anisian and Ladinian of the High-Tatric Unit and Anisian of the Krížna Unit is developed as black limestones intercalated with grey dolostones, while Ladinian of the Krížna Unit is dominated by dolostones.
The set of sedimentary features indicates that the Middle Triassic succession of Tatricum and Fatricum was deposited on restricted carbonate ramp under relatively hot and arid climate conditions. Isolated basins with facies typical for low energy environments were exposed to influence of subtropical storms (Jaglarz and Szulc, 2003; Rychliński and Szulc, 2005; Jaglarz and Uchman, 2010).

The basins were emerged at the end of Ladinian (Rychliński and Szulc, 2005; Rychliński, 2008; Jaglarz, 2010). The CarnianNorian succession of Tatricum and Fatricum units is developed as two facies of the Carpathian Keuper: sandstone-mudstone 
and dolostone-dolomitic mudstone (Turnau-Morawska, 1953; Kotański, 1956b, 1959a, b, 1979a). Siliciclastic deposits represent fluvial facies, while dolostone-dolomitic mudstone facies were deposited in marginal marine environment heavily influenced by continent (Al-Juboury and Durovič, 1996; Rychliński, 2008; Jaglarz, 2010).

Middle Triassic succession of High-Tatric and Krížna units is generally characterized by a scarcity of index fossils. Benthic foraminifera, calcareous algae, crinoids, brachiopods, bivalves and gastropods date on Anisian age the lower part of the Middle Triassic succession from the High-Tatric Unit (Rabowski, 1931; Lefeld, 1958; Bac and Grochocka, 1965; Piotrowski, 1965; Niedźwiedzki and Salamon, 2006; Rychliński et al., 2008), whereas the upper part of disscussed rock complex (Ladinian) is not palaeontologically substantiated (Kotański, 1979a). In Krížna Unit, Anisian part of the Middle Triassic succession is dated by calcareous algae, crinoids and brachiopods (Uhlig, 1897; Kotański, 1958; 1963, 1965, 1967, 1973; Niedźwiedzki and Salamon, 2006), whereas the Ladinian part is determined basing on calcareous algae (Kotański, 1963, 1965, 1967).

Norian age of Carpathian Keuper succession of the Krížna Unit was indicated by spores, pollens and benthic foraminifera (Gaździcki, 1983; Fijałkowska and Uchman, 1993), whereas Carpathian Keuper of the High-Tatric Unit is not palaeontologically dated.

\section{PREVIOUS STUDIES ON BENTHIC FORAMINIFERA AND CALCAREOUS ALGAE FROM THE ANISIAN-NORIAN SUCCESSION IN THE TATRA MTS.}

\section{Benthic foraminifera}

For many years sedimentary rocks of the Tatra Mts have been subject of micropalaeontological investigations. The first article dedicated to foraminifera study from the Tatra Mts was published by O. Saxl (in: Goetel, 1917) and was devoted to the Upper Triassic foraminifera.

The Middle Triassic foraminifera from the High-Tatric Unit were described by Bełka and Gaździcki (1976). The assemblage of Anisian foraminifera includes stratigraphycally important forms. The species Ammodiscus incertus (d'Orbigny), Glomospira densa (Pantić), Glomospirella grandis (Salaj), G. triphonensis (Baud, Zaninetti and Broennimann) and five genera with open nomenclature have been specified at the Kominiarski Wierch section. This association indicated the latest Early Anisian, through Early Illyrian age.

Anisian foraminifera from the Ogarle-Opalone scale (HighTatric Unit, Giewont nappe) were described by Gaździcki and Lipiec (1995). The foraminifera recognized at the Ogarle section in the Kondratowa Valley include stratigraphically important taxa such as: Glomospira densa Pantić, Glomospirella grandis (Salaj) and Meandrospira dinarica Kochansky-Dévide and Pantić. According to the authors, their stratigraphic range coincides with the Glomospira densa Zone (Bithynian-Illyrian).

Dolostones from uppermost part of the Carpathians Keuper succession from the Lejowa Valley section (Križna Unit) contains Agathammina austroalpina Kristan Tollmann and Tollmann (Gaździcki, 1983).

The stratigraphically important foraminifera assemblages from the Choč nappe in the Tatra Mts were described for the first time by Gaździcki and Zawidzka (1973). The association found in limestones from the Wielkie Koryciska Valley includes following species: Ammobaculites cf. radstadtensis KristanTollmann, Calcitornella? sp., Hemigordius? chialingchaingensis (Ho), Trochammina almtalensis Koehn-Zaninetti, Turritellella mesotriassica Koehn-Zaninetti. This association indicates Upper Anisisan (Illyrian) age. Well preserved few foraminifera of Anisian age (such as: Glomospirella shengi Ho, Trochamminoides pusillus Ho, Trochammina cf. pulvila Crespin and Parr, Pachyphloides klebelsbergi (Oberhauser), Geinitzinita oberhauseri Sellier, Civrieux and Dessauvagie, Pseudonodosaria simpsonensis (Tappan), Nododsaria spiculata Crespin, $N$. raggatti Crespin, N. ordinata Trifonova, Dentalina cf. turgoidea Kristan-Tollmann, Lenticulina (Vaginulinopsis) cryptospira (Paalzow), Marginulina solida Terquem, Lenticulina (Astacolus) karnica (Oberhauser) were described by Alexandrowicz and Szewczyk (1981) from marls and limestones of the Wielkie Koryciska Valley (Choč nappe). However, these assemblages (dominated by representatives of the Nodosariidae family) are not sufficient to define biostratigraphic zones.

\section{Calcareous algae}

Calcareous algae, such as Physoporella pauciforata (Gümbel), P. prealpina Pia, P. dissita (Gümbel), P. minutula (Gümbel), Diplopora annulatissima Pia, D. helvetica Pia, D. hexaster Pia, Macroporella sp., Griphoporella sp., and Poikiloporella sp. were found within Middle Triassic succession of the High-Tatric Unit in Kominiarski Wierch and Kościeliska Valley localities and indicated the Pelsonian-Illyrian age (Bac and Grochocka, 1965; Piotrowski, 1965; Kotański, 1967, 1979a).

Calcareous algae Physoporella pauciforata (Gümbel), Physoporella prealpina Pia and Physoporella dissita (Gümbel) of Pelsonian-Illyrian age were described by Kotański (1965, 1967, 1973) from Wolarnia scale and borehole of Zakopane IG-1 (Krížna Unit). The same author (Kotański $(1963,1967)$ described Diplopora annulata var. annulata (Schafhäutl), Diplopora annulata var. dolomitica (Schafhäutl), Diplopora annulatissima Pia, D. uniserialis (Pia), Physoporella dinarica, Macroporella sp. and Teutloporella sp. from many localities at the Krížna Unit, which indicated the Fassanian age.

Based on assemblage of calcareous algae with Physoporella panciforata (Gümbel), P. prealpina Pia, P. aff. dissita (Gümbel) and Diplopora annulatissima Pia the age of diplopore and oncolitic dolostones from the Choč nappe was determined as the Late Anisian (Kotański, 1965). Early Ladinian age of Wetterstein type dolostones from the Koryciska scale (Choč nappe) was concluded on the basis of the presence of calcareous algae with Teutloporella herculea (Stoppani), T. cf. aequalis (Gümbel), T. tenuis Pia, Diplopora annulata var. dolomitica (Schafhäutl), Macroporella sp., Griphoporella sp., Acicularia sp. and Clypeina sp. (Kotański, 1967, 1973).

\section{MATERIALS AND METHODS}

About five hundred thin sections of the Triassic carbonate rocks from High-Tatric and Krížna units were analysed. Benthic foraminifera and/or calcareous algae were found in a dozen of rock samples. Foraminifera were examined in limestones and dolostones from Stoły pod Ciemniakiem, Giewont and 
Kominiarski Wierch sections (High-Tatric Unit), as well as in Łysanki, Skoruśniak, Żleb pod Czerwieniec, Hlúpy, Skupniów Upłaz and Żleb pod Czerwoną Przełęcz sections (Krížna Unit). Calcareous algae were identified in limestones of the Stoły pod Ciemniakiem section (High-Tatric Unit).

\section{DESCRIPTION OF DETERMINED SPECIES}

\section{Benthic foraminifera}

Agathammina austroalpina Kristan-Tollmann and Tollman, 1963 (Pl. I, Figs 17-18).

Sections: Skupniów Upłaz (Krížna Unit; Fig. 2A), Żleb pod Czerwoną Przełęcz (Krížna Unit; Fig. 3)

Biostratigraphical distribution: Late Anisian-Rhaetian (KoehnZaninetti, 1969).

Geographical distribution: Western Tethys: Gurktaler Alps (Kristan-Tollmann and Tolmann, 1963); Region de L'Almtal, Haute-Autriche (Koehn-Zaninetti, 1969); Trento, Northern Italy (Premoli Silva, 1971); Elika Formation, Central Albourz, Northern Iran (Zaninetti et al., 1972c); Northwest Caucasus and Cis-Caucasus (Efimova, 1974); Turkey, Austrian Alps and China (Zaninetti, 1976); Central and Southern Tunisian Atlasic Range (Kamoun et al., 1997); Pinarbasi area, eastern Taurus, Turkey (Altiner and Zaninetti, 1981); West Carpathians (Salaj et al., 1967, 1983); Slovakian and Polish Carpathians, among other from Krížna and Choč units of the Tatra Mts. (Gaździcki and Zawidzka, 1973; Gaździcki, 1974, 1983); Northern Apennines (Ciarapica et al.,1987); Transdanubian Range (Oravecz-Scheffer, 1987); Lienzer Dolomiten, Eastern Tirol, Austria (Blau and Schmidt, 1990); Corsica, Balagne Autochthon (Peybernès et al., 1991); Northeastern Iberian Peninsula (Arnal et al., 2002); Kalkwendel range, Northern Calcareous Alps, Austria (Nittel, 2006; SW Cyprus (Martini et al., 2009). Eastern Tethys: Yushu Region, Qinghai, Northwest China (He and Wang, 1990); Sambosan Accretionary Complex, southern Kyushu, Japan (Chablais et al., 2010a); Southwestern Japan (Chablais et al., 2010b, 2011).

Agathammina? iranica Zaninetti, Brönnimann, Bozorgnia and Huber, 1972c (Pl. I, Fig.16).

Section: Stoły pod Ciemniakiem (High-Tatric Unit; Fig. 4B).

Biostratigraphical distribution: Middle-Late Anisian (Bucur et al., 1997) - Norian-Raethian Zaninetti (1976).

Geographical distribution: Elika Formation, Iran (Zaninetti et al., 1972c); Turkey, Austrian Alps and China (Zaninetti, 1976); Pinarbasi, Taurus oriental, Turkey (Altiner and Zaninetti, 1981); NE of Oravita, Southern Carpathians, Rumania (Bucur et al., 1997); Southwestern Japan (Chablais et al., 2011).

Aulotortus ex. gr. praegaschei (Koehn-Zaninetti, 1969) (Pl. I, Figs 2-4).

Section: Skupniów Upłaz (Krížna Unit; Fig. 2A); Żleb pod Czerwoną Przełęcz (Krížna Unit; Fig. 3).

Biostratigraphical distribution: Ladinian-Carnian (Zaninetti, 1976) - Norian-Rhaetian (Kamoun et al., 1994).

Geographical distribution: Almtal region, Austria (KoehnZaninetti and Brönnimann, 1968; Koehn-Zaninetti, 1969); Turkey, Austrian Alps and China (Zaninetti, 1976); Taurus Mts., Turkey (Dager, 1975); Inner Carpathians (Salaj et al., 1983);
Yushu region, Qinghai, Northwest China (He and Wang, 1990); Corsica, France (Peybernès et al., 1991); Baise Basin, Guangxi, China (He and Cai, 1991); Bulgaria (Trifonova, 1993); southern part of Tunisia (Peybernès et al., 1993); Fkirine Formation, Central Tunisia (Kamoun et al. 1994); Central and Southern Tunisian Atlasic Range (Kamoun et al., 1997); Arabian shelf in the northern United Arab Emirates (Maurer et al., 2008).

Comment: Ciarapica and Zaninetti $(1984,1985)$ made a revision of the type material and listed some foraminifera as synonym with Aulotortus friedli. However, Aulotortus gaschei praegaschei were showned as separate species with synonyms but not conspeciffic with $A$. friedli.

Aulotortus ex. gr. ?sinuosus Weynschenk, 1956 (Pl. I, Fig. 4). Section: Żleb pod Czerwoną Przełęcz (Krížna Unit; Fig. 3).

Biostratigraphical distribution: Ladinian (Zaninetti, 1976) Middle Jurassic (Weynschenk 1956).

Geographical distribution: Turkey, Austrian Alps and China (Zaninetti, 1976); Western Carpathians, among other from Krížna and Choć units in the Tatra Mts. (Gaździcki, 1974, 1983; Gaździcki and Michalík, 1980); Inner Carpathians (Salaj et al., 1983); Northern Apennines (Ciarapica et al., 1987); Transdanubian Range (Oravecz-Scheffer, 1987); Lienzer Dolomiten, Osttirol, Austria (Blau and Schmidt, 1990); Bulgaria (Trifonova, 1993); Alsó Hill, Northern Hungary (Bérczi-Makk, 1996b); Karwendel range, Northern Calcareous Alps (Nittel, 2006); Urbut section, north of Izmir, Turkey (Okay and Altiner, 2007); SW Cyprus (Martini et al., 2009); Dachstein Plateau, Northern Calcareous Alps, Upper Austria and Styria (Haas et al., 2010).

In Italy, A. sinuosus was found in the Northern Apennines, at La Spezia (Ciarapica and Zaninetti, 1984); at Monte Cetona (Ciarapica and Zaninetti, 1985); at Verbicaro unit, Lucania and Calabria, Southern Italy (Climaco et al., 1997) and at the Northeastern Cortina d'Ampezzo - Tamarin, San Cassiano Formation, Dolomites (Di Bari and Baracca, 1998).

In the eastern Tethys (East and South East Asia): Yushu region, Qinghai, Northwest China (He and Wang, 1990); Sinta Ridge, Banda Sea, Indonesia (Villeneuve et al., 1994); Eastern Sulawesi, Indonesia (Martini et al., 1997); Seram, Indonesia (Martini et al., 2004) and Lampang Group, Northern Thailand (Kobayashi et al., 2006).

Dentalina cf. zlambachensis Kristan-Tollmann, 1964 (Pl. I, Fig. 28). Section: Hlúpy (Krížna Unit; Fig. 2B).

Biostratigraphical distribution: Ladinian-Rhaetian (Trifonova, 1994). Geographical distribution: West of Bad Aussee/Salzkammergut, Styria and Upper (Kristan-Tollmann, 1964); Transdanubian Range (Oravecz-Scheffer, 1987); Bulgaria (Trifonova, 1994).

Diplotremina ?astrofimbriata Kristan-Tollmann, 1960 (Pl. I, Fig. 11). Section: Kominiarski Wierch (High-Tatric Unit; Fig. 4A).

Biostratigraphical distribution: Anisian (Premoli Silva, 1971) Norian (Salaj et al. 1983).

Geographical distribution: 'Cassianer Schichten' of Eastern Alps (Kristan-Tollmann, 1960); Trento, Northern Italy (Premoli Silva, 1971); West Carpathians (Salaj et al., 1983); localities Kumaun and Hundes, Himalayas (Kristan-Tollmann, 1984); Central and 


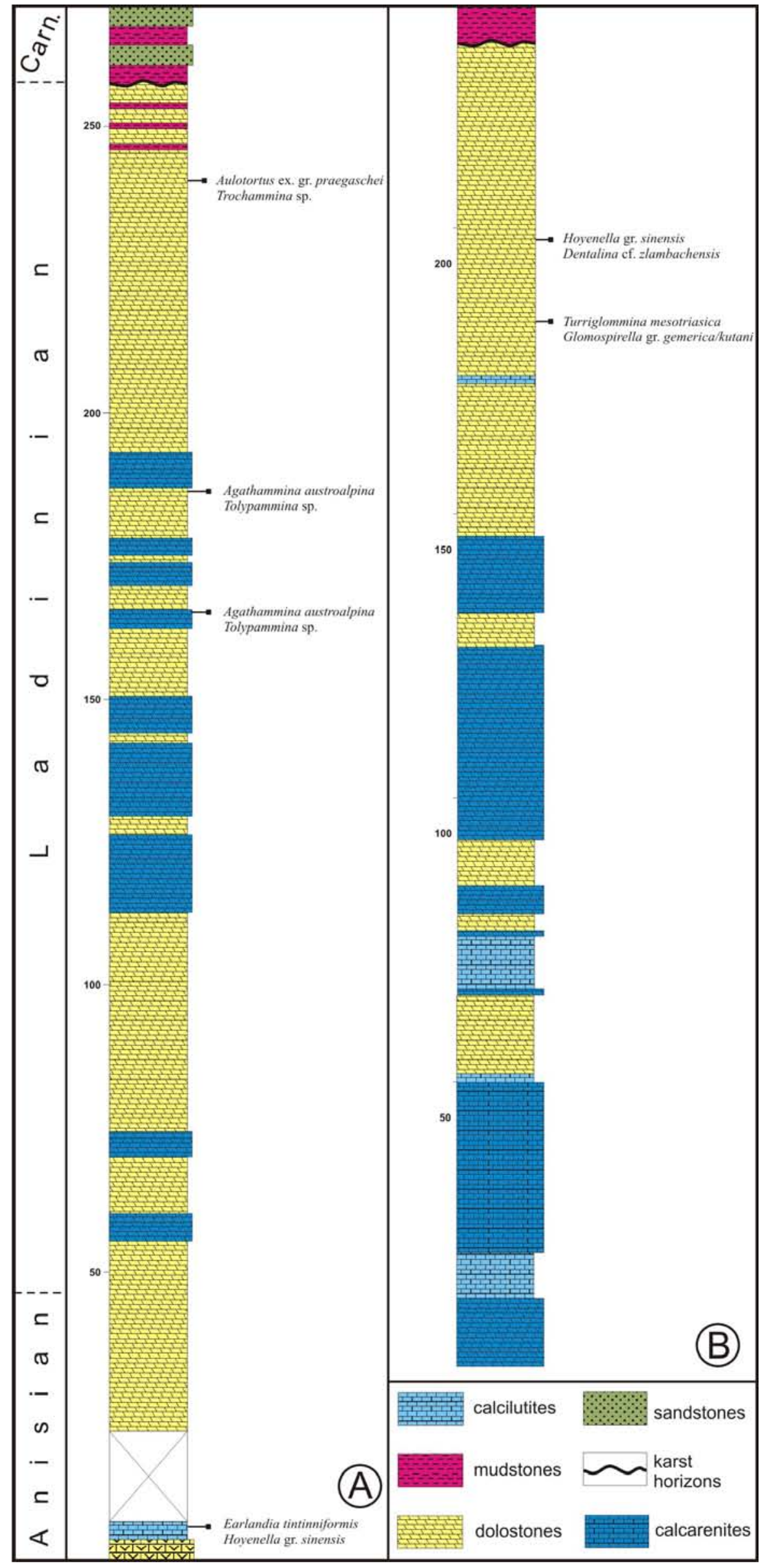

Fig. 2. Sketch-sections of the Middle Triassic from the Križna Unit with marked position of discovered foraminifera. a) Skupniów Upłaz section; b) Hlúpy section. 


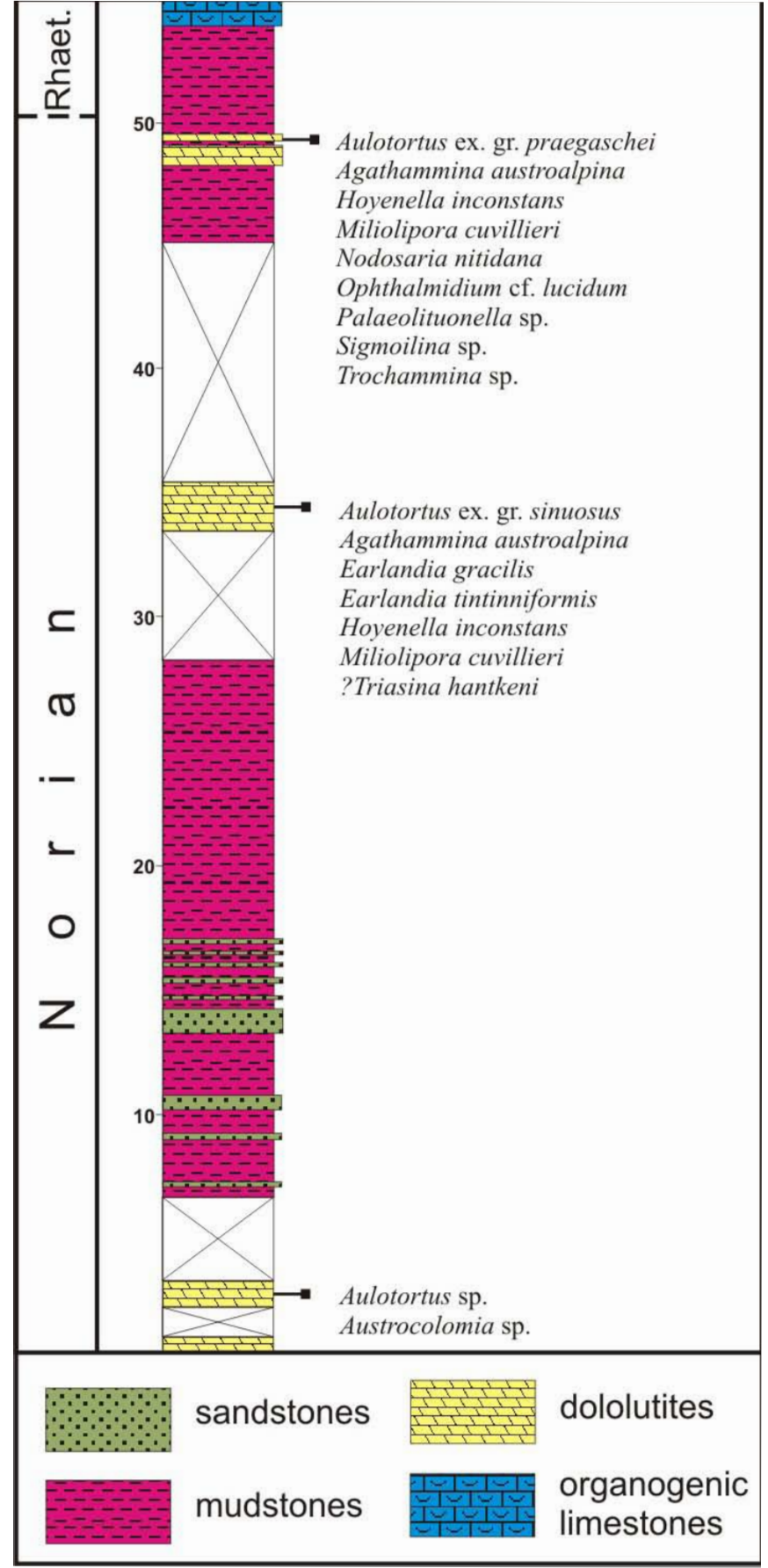

Fig. 3. Sketch of Żleb pod Czerwona Przełęcz section (Križna Unit) with marked position of discovered foraminifera.

Southern Guizhou, China (He, 1984); Transdanubian Range (Oravecz-Scheffer, 1987); Castle Hill in Bled, northwestern Slovenia (Flügel et al., 1994); Sasca Zone, Southern Carpathians, Romania (Bucur et al., 1994); Kurosegawa Terrane, Japan (Kobayashi et al, 2005); Lampang Group, Northern Thailand (Kobayashi et al., 2006); Slovenian basin, Southern Alps, Slovenia (Gale et al., 2011).

Earlandia gracilis Pantić, 1972 (Pl. I, Fig. 22).

Section: Żleb pod Czerwoną Przełęcz (Krížna Unit; Fig. 3).

Biostratigraphical distribution: Spathian (Trifonova, 1992) Cordevolian (Bérczi-Makk, 1996a, b, c).

Geographical distribution: Mratinje, Montenegro (Pantić, 1972); Turkey, Austrian Alps and China (Zaninetti, 1976); West Carpathians
(Salaj et al., 1983); Central Balkanides and Vlahina Mt., South West Bulgaria (Trifonova, 1992); Nádaska Limestone Formation of Alsó Hill, Nothern Hungary (Bérczi-Makk, 1996a, b, c).

\section{Earlandia tintinniformis (Mišik, 1971) (Pl. I, Fig. 23).}

Sections: Skupniów Upłaz (Krížna Unit, Fig. 2A), Żleb pod Czerwoną Przełęcz, (Krížna Unit, Fig. 3).

Biostratigraphical distribution: Early to Late Triassic (Zaninetti, 1976).

Geographical distribution: Préalpes médianes rigides, Diemtigtal, Switzerland (Zaninetti et al., 1972b); Bosnia and Herzegovina (Brönnimann et al., 1973b); Turkey, Austrian Alps and China (Zaninetti, 1976); West Carpathians (Salaj et al., 1983); Transdanubian Range (Oravecz-Scheffer, 1987); Lienzer Dolomiten, Eastern Tirol, Austria (Blau and Schmidt, 1990); Bulgaria (Trifonova, 1992); Castle Hill in Bled, Northwestern Slovenia (Flügel et al., 1994); Hydra Island, Greece (Rettori et al., 1994); Alsó Hill, Nothern Hungary (Bérczi-Makk, 1996 b); Iberian Peninsula, Spain (Arnal et al., 2002).

Glomospirella gr. gemerica/kutani (Salaj, 1969).

Section: Hlúpy (Krížna Unit; Fig. 2B).

Biostratigraphical distribution: Ladinian-Carnian (Salaj et al., 1983). Geographical distribution: Slovak Karst, West Carpathian (Salaj in: Salaj, Biely and Bystrický, 1967); Turkey, Austrian Alps and China (Zaninetti, 1976); Slovakian and Polish Carpathians (Gaździcki, 1983); West Carpathians (Salaj et al., 1983); Transdanubian Central Range (Oravecz-Scheffer, 1987); Bulgaria (Trifonova, 1992); Alsó Hill, Northern Hungary (Bérczi-Makk, 1996b); Arabian shelf in the northern United Arab Emirates (Maurer et al., 2008); Southwestern Japan (Chablais et al., 2011).

Comment: Peybernès et al. (1993) determinate Glomospirellinae such as Pilamminella (=Glomospirella ?) gemerica (Salaj) and P. kuthant (Salaj) and draws attention to the fact that these closely related species often amalgamated as Pilammmella gr. gemericakuthani. As it is very difficult to define the specific features of these two taxa, especially with a low number of specimens, we agree with the suggestion of Peybernès et al. (1993) and Maurer et al. (2008) to attribute our few specimens to the Glomospirella kuthani/gemerica group.

Glomospirella triphonensis Baud, Zaninetti and Brönnimann, 1971. Section: Łysanki (Krížna Unit; Fig. 5C).

Biostratigraphical distribution: Olenekian-Anisian (Rettori, 1995). Geographical distribution: Préalpes Médianes, Préalpes Romandes, Switzerland and the Chablais Préalpes, France (Baud, Zaninetti and Brönnimann, 1971); Southern Poland (Gaździcki et al., 1975); High-Tatric Unit in the Tatra Mts. (Bełka and Gaździcki, 1976); Turkey, Austrian Alps and China (Zaninetti, 1976); Jelovica river valley, Southeastern Serbia (Pantić-Prodanović and Radosević, 1977); West Carpathians (Salaj et al., 1983); Transdanubian Central Range (OraveczScheffer, 1987); Bulgaria (Trifonova, 1992); North Hessen, Germany (Blau et al., 1995); Tethyan domain (Rettori, 1995); Karatash Group, Southeastern Pamir (Korchagin, 2008).

Glomospirella vulgaris Ho, 1959 (Pl. I, Fig. 5, 6).

Section: Stoły pod Ciemniakiem (High-Tatric Unit; Fig. 4B). Biostratigraphical distribution: Smithian-Anisian (Rettori, 1995). 


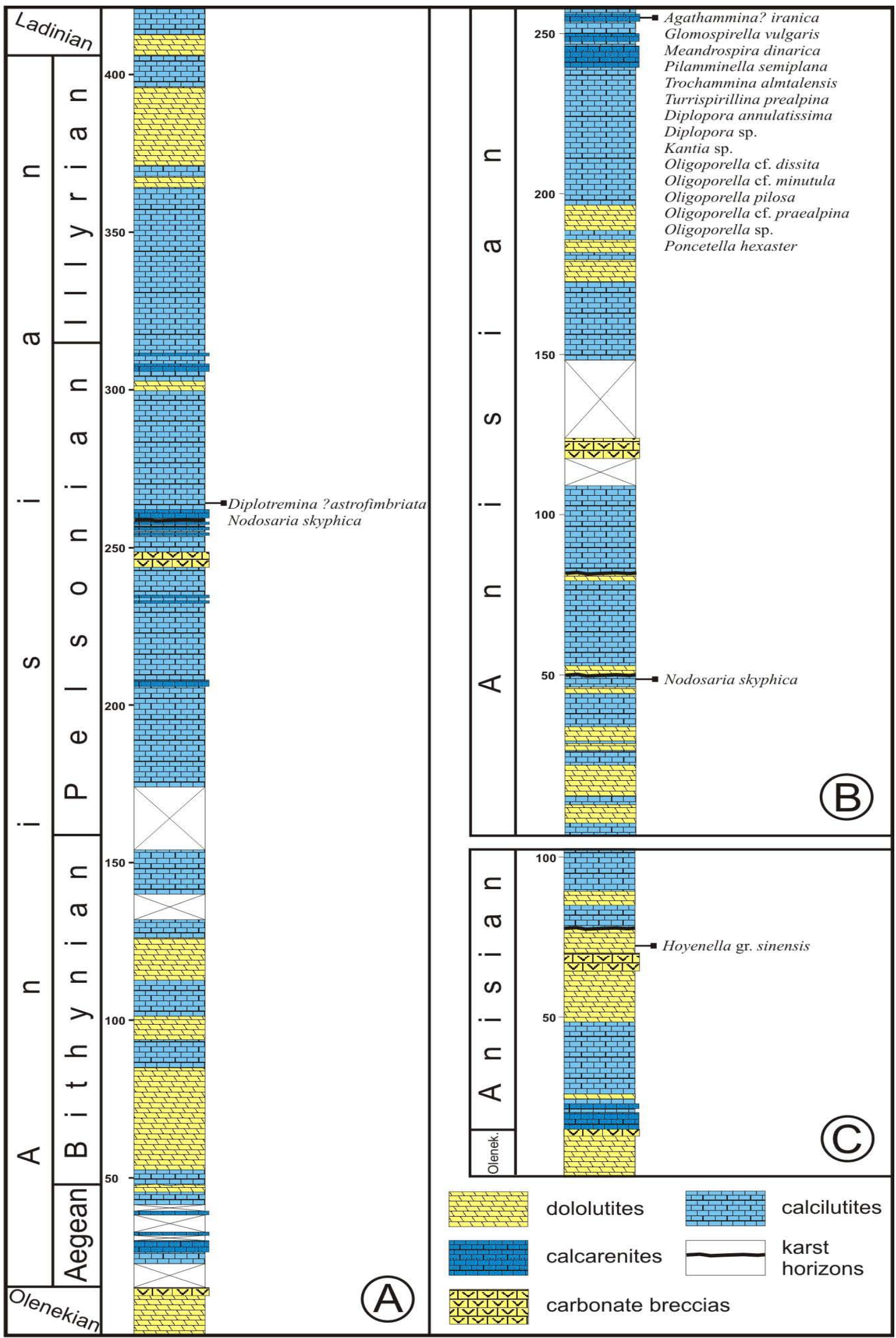

Fig. 4. Sketch-sections of the Anisian rocks from the High-Tatric Unit with marked position of discovered microfossils. a) Kominiarski Wierch section; chronostratigraphy after Jaglarz and Szulc (2003), modified; b) Stoły pod Ciemniakiem section (section inverted in the field); c) Giewont section. 
Geographical distribution: Chialingkiang Limestone of South Szechuan, China (Ho, 1959); Northwest Caucasus and CisCaucasus (Efimova, 1974); Southern Poland (Gaździcki et al., 1975); Turkey, Austrian Alps and China (Zaninetti, 1976; Rettori, 1995); Bulgaria (Trifonova, 1992); countries of Sichuan and of Shaanxi, China (He, 1993); Tethyan domain (Rettori, 1995);

Comment: Rettori (1995) conducted a revision of Ho's material (Ho, 1959) and included in the synonym list of the species Glomospirella vulgaris the species listed as: Ammodiscus incertus, A. semiconstrictus, A. planus, A. multivolutus, Glomospira articulosa, G. gordialis, G. sygmoidalis, Glomospirella irregularis, G. spirilinoides, and G. ammodiscoidea as well as the species Glomospirella irregulariformis described as new by Efimova (1974).

Hoyenella inconstans (Michalík, Jendrejáková and Borza, 1979) (Pl. I, Figs 14, 15).

Section: Żleb pod Czerwoną Przełęcz (Krížna Unit; Fig. 3).

Biostratigraphical distribution: Carnian-Norian to Rhaetian (Kamoun et al., 1994).

Geographical distribution: Western Tethyan domain: Sub-Tatric (Krížna) of the Tatra Mts. (Gaździcki, 1974); West Carpathians (Salaj et al., 1983); Slovakian and Polish Carpathians (Gaździcki, 1983); Northern Apennines (Ciarapica et al., 1987); southern part of Tunisia (Peybernès et al., 1993); Tethyan realm (Rettori, 1994); Fkirine Formation, Central Tunisia (Kamoun et al., 1994); Central and Southern Tunisian Atlasic Range (Kamoun et al., 1997); Northeastern Iberian Peninsula (Arnal et al., 2002); Punta Bassano, Marettimo Island, Sicily (Martini et al., 2007).

In the eastern Tethys (East and South East Asia): Sambosan Accretionary Complex, southern Kyushu, Japan (Chablais et al., 2010a) and Southwestern Japan (Chablais et al., 2010b, 2011).

Comment: The species was introduced as Glomospira inconstans by Michalík, Jendrejáková and Borza in 1979. Later, Rettori (1994) referred representatives of the species: Glomospira inflata, Glomospirella fatrica, Glomospirella minima, and Glomospirella paucispira to the new genus and respectively, to the new Late Triassic combination of Hoyenella inconstans with Glomospira inconstans Michalík, Jendrejáková and Borza type species.

\section{Hoyenella gr. sinensis (Ho, 1959).}

Sections: Giewont (High-Tatric Unit; Fig. 4C), Żleb pod Czerwieniec (Krížna Unit; Fig. 5A), Skoruśniak (Krížna Unit; Fig. 5B), Skupniów Upłaz, Hlúpy (Krížna Unit; Fig. 2A).

Biostratigraphical distribution: Olenekian-Anisian, cosmopolitan (Rettori, 1995).

Geographical distribution: Well known from the Tethyan domain: South Szechuan, China (Ho, 1959); Dinarids and Western Carpathians (Salaj et al., 1967; Michalík et al., 1979; Salaj et al. 1983); Préalpes Romandes, Switzerland and the Chablais Préalpes, France (Baud et al., 1971); Sorkh shale formation, Tabas area, east-central Iran (Brönnimann et al., 1973c); Northwest Caucasus and Cis-Caucasus (Efimova, 1974); Southern Poland (Gaździcki et al., 1975); Kocaeli Peninsula, Western Turkey (Dager, 1978); Transdanubian Range (OraveczScheffer, 1987); Internal Hellenides, Northern Greece (Baroz et al., 1990); Bulgaria (Trifonova, 1992); Weser Basin, Hesse, Northern Germany (Martini et al., 1996); Maizuru Terrane, Japan (Kobayashi, 2008).
Comment: Rettori (1994) introduced the new family Hoyenellidae, fam. n. (type-genus Hoyenella, gen. n.) and new Hoyenella genus, gen. n. (type-species: Glomospira sinensis Ho, 1959). The following species: Glomospira sinensis var. rara Ho, Glomospirella facilis Ho, Glomospirella shengi Ho, Glomospirella elbursorum Brönnimann et al., 1972; Palaeonubecularia minuta Brönnimann et al., 1972; Calcitornella gebzeensis Dager, 1978 and Palaeonubecularia? floriformis n.sp. Ciarapica and Zaninetti, 1984, the author attributed to the genus Hoyenella. Revision of the material type of the species Glomospira sinensis showed, that the porcelaneous wall and the miliolid enrollment of the test, did not allow for referring this foraminifera to the genus Glomospira Rzehak at least in the initial portion. Rettori (1994) unified these species in one "group" and named it Hoyenella gr. sinensis (Ho).

Meandrospira dinarica Kochansky-Devidé and Pantić, 1966 (Pl. I, Figs 12, 13).

Section: Stoły pod Ciemniakiem (High-Tatric Unit; Fig. 4B).

Biostratigraphical distribution: Anisian (Rettori, 1995).

Geographical distribution: Dinarids (Pantić, 1964; KochanskyDevidé and Pantić, 1966); Préalpes médianes rigides, Switzerland and France (Baud et al., 1971; Zaninetti et al., 1972a, b); Trento, Northern Italy (Premoli Silva, 1971); Bosnia and Herzegovina (Brönnimann et al., 1973a, b); Eastern Hellenic zone, Greece (Christodoulou and Tsaila-Monopolis, 1972); Tabas area, East-Central Iran (Brönnimann et al., 1973a); Northwest Caucasus and Cis-Caucasus (Efimova, 1974); Southern Poland (Gaździcki et al., 1975); Jelovica river valley, Southeastern Serbia (Pantić-Prodanović and Radosević, 1977); Kocaeli Peninsula, Turkey (Dager, 1978); West Carpathians (Salaj et al., 1983); Transdanubian Range (Oravecz-Scheffer, 1987); Internal Hellenides, Northern Greece (Baroz et al., 1990); Bulgaria (Trifonova, 1993); Chios Island, Greece (Muttoni and Rettori, 1993); Pusteria valley, Dolomites, NE Italy (Zaninetti et al., 1994b); Dinarids and Hellenids (Zaninetti et al., 1994a); Castle Hill in Bled, Northwestern Slovenia (Flügel et al., 1994); Sasca Zone, Southern Carpathians, Romania (Bucur et al., 1994); Eros Limestones, Hydra Island, Greece (Rettori et al., 1994); HighTatric Unit in the Tatra Mts. (Gaździcki and Lipiec, 1995); Alsó Hill, Northern Hungary (Bérczi-Makk, 1996a); Lombardy basin, Italy (Berra et al., 2005); Karwendel range, Northern Calcareous Alps (Nittel, 2006).

In the eastern Tethys (East and South East Asia): China (Sichuan: Ho, 1959; Guizhou: He, 1984); Japan (Kaizawa Formation, Kurosegawa Terrane: Kobayashi, 1996; Tanoura Formation, Kurosegawa Terrane: Kobayshi et al., 2005; Maizuru Terrane: Kobayashi, 2008); Lampang Group, Northern Thailand (Kobayashi et al., 2006).

Miliolipora cuvillieri Brönnimann and Zaninetti in Brönnimann, Zaninetti, Bozorgnia, Dashti and Moshtaghian, 1971 (Pl. I, Fig. 10). Section: Żleb pod Czerwoną Przełęcz (Krížna Unit; Fig. 3).

Biostratigraphical distribution: Carnian (Bérczi-Makk. 1996 b) to Rhaetian, characteristic for the Norian-Rhaetian interval (Chablais et al., 2010a, b).

Geographical distribution: Nayband Formation, Iran (Brönnimann et al., 1971); Sub-Tatric (Krížna) of the Tatra Mts, where it is described as Miliolipora sp. (Gaździcki, 1974); Turkey, Austrian Alps and China (Zaninetti, 1976); Taurus, Turkey (Zaninetti et al., 1982); West Carpathians (Salaj et al., 1983); Transdanubian Range (Oravecz-Scheffer, 1987); 


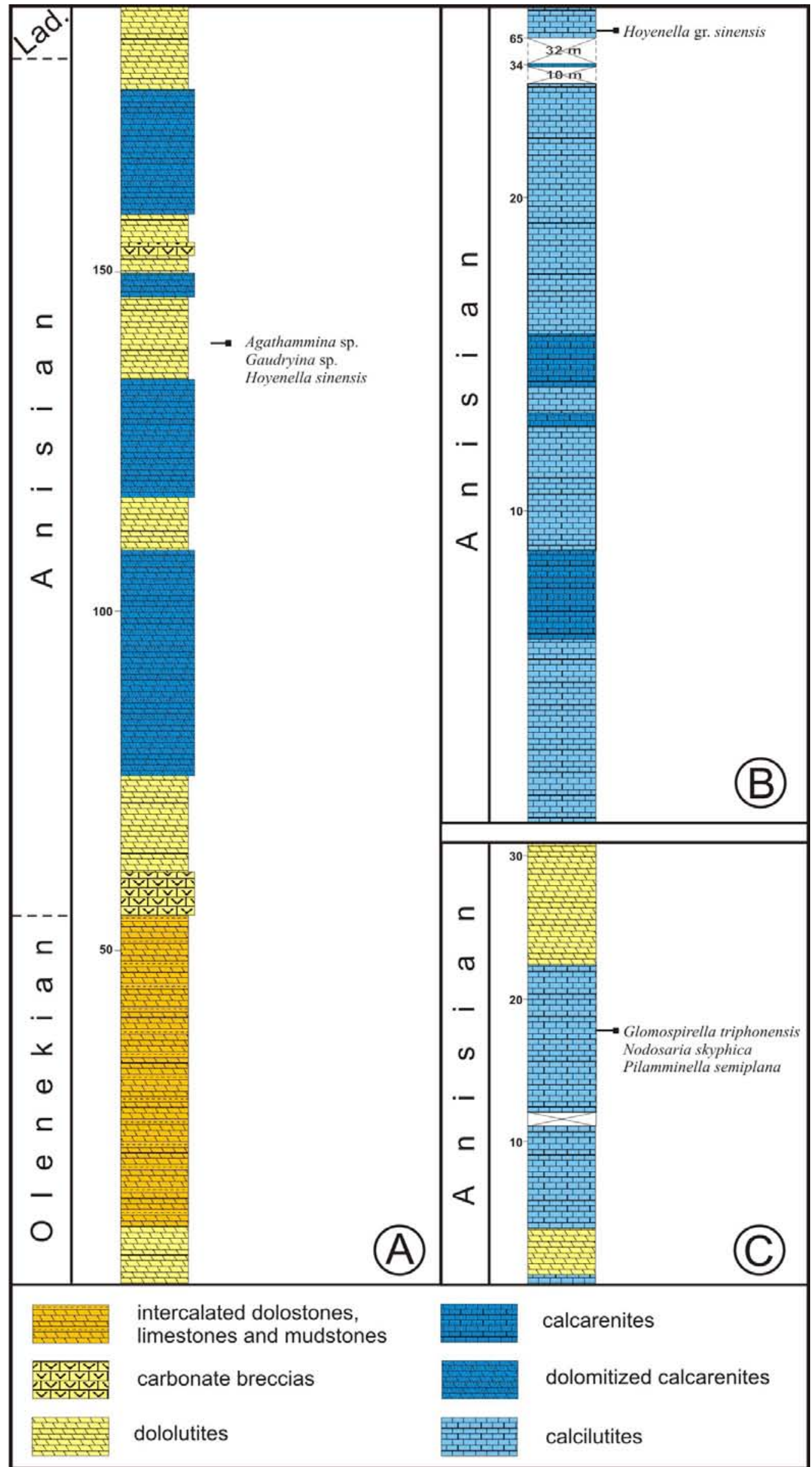

Fig. 5. Sketch-sections of the Triassic rocks from the Križna Unit with marked position of discovered foraminifera. a) Żleb pod Czerwieniec section; b) Skoruśniak section; c) Eysanki section. 
Bulgaria (Trifonova, 1994); Alsó Hill, Northern Hungary (Bérczi-Makk, 1996b); SW Cyprus (Martini et al., 2009); Dachstein Plateau, Northern Calcareous Alps, Upper Austria and Styria (Haas et al., 2010).

In the eastern part of the Tethyan: Banda Sea, Sinta Ridge (Villeneuve et al., 1994); Eastern Sulawesi, Indonesia (Martini et al., 1997); Sambosan Accretionary Complex, western Shikoku Island, Japan (Chablais et al., 2010a); Southwestern Japan (Chablais et al., 2010b, 2011).

Nodosaria nitidana Brand, 1937 (Pl. I, Fig. 27).

Section: Żleb pod Czerwoną Przełęcz (Krížna Unit; Fig. 3).

Biostratigraphical distribution: Carnian-Early Jurassic (Di Bari and Baracca, 1998).

Geographical distribution: West of Bad Aussee/Salzkammergut, Styria and Upper Austria (Kristan-Tollmann, 1964); West Carpathians (Salaj et al., 1983); Slovakian and Polish Carpathians (Gaździcki, 1983); Transdanubian Central Range (OraveczScheffer, 1987); Bulgaria (Trifonova, 1994); Northeastern Cortina d'Ampezzo - Tamarin, San Cassiano Formation, Dolomites (Di Bari and Baracca, 1998).

\section{Nodosaria skyphica Efimova, 1974 (Pl. I, Figs 25, 26).}

Sections: Stoły pod Ciemniakiem, Kominiarski Wierch (HighTatric Unit; Fig. 4A-B), Łysanki (Krížna Unit; Fig. 5C).

Biostratigraphical distribution: Late Permian-Late Triassic (Groves et al., 2005).

Geographical distribution: China (Ho, 1959; He, 1988); Northwest Caucasus and Cis-Caucasus (Efimova, 1974); Epidaurus area, Peloponnesus, Greece (Scourtsis-Coroneou et al., 1992); Bulgaria (Trifonova, 1994); Kaizawa Terrane, Japan (Kobayashi, 1996); Oravita region, Southern Carpathians, Romania (Bucur et al., 1997); Gevne Formation at the Tashkent section, Central Taurides, Turkey (Groves et al., 2005); PermianTriassic boundary sections in Southern Alps, Northern Italy (Groves et al., 2007). The species was figured out and determined as Nodosaria sp. also from High-Tatric series of the Tatra Mts by Bełka and Gaździcki (1976).

Comments: Efimova (1974) introduced two new species: Nodosaria hoi and Nodosaria piricamerata. Groves et al. (2005, 2007) conducted detailed research on End-Permian mass extinction of Lagenide Foraminifera in the Southern Alps (Northern Italy) and concluded that Nodosaria skyphica Efimova, 1974 (=N. hoi skyphica Efimova, 1974) and $N$. piricamerata Efimova, 1974 are synonyms, this fact we also accept. According to the revised work of Gaillot and Vachard, 2007 species attributable to $N$. hoi should refer to the group Polarisella ex. gr. hoae (Trifonova).

Ophthalmidium cf. lucidum (Trifonova, 1962).

Section: Żleb pod Czerwoną Przełęcz (Krížna Unit; Fig. 3).

Biostratigraphical distribution: Carnian-Rhaetian (Trifonova, 1993).

Geographical distribution: East Balkan Mts., Bulgaria (Trifonova, 1993); Sub-Tatric (Krížna) of the Tatra Mts. (described and figured as Ophthalmidium sp.) (Gaździcki, 1974); West Carpathians (Salaj et al., 1983); Wetterstein Limestone Formation, Alsó Hill, Northern Hungary (Bérczi-Makk, 1996b).

Pilamminella semiplana (Kochansky-Devidé and Pantić, 1966) (Pl. I, Figs 7-9).
Sections: Stoły pod Ciemniakem (High-Tatric Unit; Fig. 4B), Łysanki (Krížna Unit; Fig. 5C).

Biostratigraphical distribution: Anisian-Late Triassic, most widespread in the middle-upper Anisian (Rettori, 1995).

Geographical distribution: western part of the Tethyan realm: Dinarids (Kochansky-Devide and Pantić, 1966); Almtal region, Austrian Alps (Koehn-Zaninetti, 1969); Trento, Northern Italy (Premoli Silva, 1971); Préalpes médianes rigides, Switzerland and France (Baud et al., 1971); Eastern Hellenic zone, Greece (Christodoulou and Tsaila-Monopolis, 1972); Bosnia and Herzegovina (Brönnimann et al., 1973a, b); Lower Silesia in Poland (Głazek et al., 1973); Northwest Caucasus and CisCaucasus (Efimova, 1974); Southern Poland (Gaździcki et al., 1975); Tatra Mts. in Poland (Bełka and Gaździcki, 1976); Turkey, Austrian Alps and China (Zaninetti, 1976); Jelovica river valley, Southeastern Serbia (Pantić-Prodanović and Radosević, 1977); Kocaeli Peninsula, Turkey (Dager, 1978); West Carpathians (Salaj et al., 1983); Transdanubian Range (OraveczScheffer, 1987); Bulgaria (Trifonova, 1992); Chios Island, Greece (Muttoni and Rettori, 1993); Dolomites, North-east Italy (Zaninetti et al., 1994b); Dinarids and Hellenids (Zaninetti et al., 1994a); Sasca Zone, Southern Carpathians, Romania (Bucur et al., 1994); Eros Limestones, Hydra Island (Rettori et al., 1994); Tethyan region (Rettori, 1995); Nordhessen, Germany (Blau et al., 1995); Weser Basin in Hesse, Northern Germany (Martini et al., 1996); Alsó Hill, Northern Hungary (Bréczi-Makk, 1996); Southern Carpathians, Rumania (Bucur et al., 1997); Lombardy basin, Italy (Berra et al., 2005); Karwendel range, Northern Calcareous Alps (Nittel, 2006).

In the East and South East Asia: China (Sichuan: Ho, 1959; Guizhou: He, 1984; Yushu region, Qinghai: He and Wang, 1990) and Japan (Kobayashi, 1996, 2008; Kobayshi et al., 2005; and Maizuru Terrane of the Yakuno area, Kyoto Prefecture: Kobayshi, 2008).

Comment: According the revision made by Rettori (1995) of the both species and in agreement with the law of priority of ICZN, the species Pilammina grandis Salaj, in Salaj, Biely and Bystrický, 1967) is a junior synonym of the species Pilammina semiplana (Kochansky-Devidé and Pantić, 1966).

?Triasina hantkeni Majzon, 1954, emend. Koehn-Zaninetti, 1968 (Pl. I, Fig. 30).

Section: Żleb pod Czerwoną Przełęcz (Krížna Unit; Fig. 3).

Biostratigraphical distribution: Norian (Sevatian)-Rhaetian, cosmopolitan (Di Bari and Rettori, 1996).

Geographical distribution: Yugoslavian Inner Dinarids (Pantić and Rampnoux, 1972); Eastern Hellenic Zone (Christodoulou and Tsaila-Monopolis, 1972); Upper Sub-Tatric (Choč) of the Western Carpathian, among other the Tatra Mts. (Gaździcki and Zawidzka, 1973; Gaździcki and Michalík, 1980; Gaździcki, 1983); Lower Sub-Tatric (Krížna) of the Western Carpathian, among other the Tatra Mts. (Gaździcki, 1974, 1983); Taurus Mts, Turkey (Dager, 1975); Europe and Asia (Al-Shaibani et al., 1982); West Carpathians (Salaj et al., 1983); Northern Apennines (Ciarapica et al. 1987); Transdanubian Range (Oravecz-Scheffer, 1987); Wombat plateau, Northwest Australia (Zaninetti et al., 1992); Sella Group Piz Boé, Western Dolomites, Italy (Di Bari and Rettori, 1996); Central and Southern Tunisian Atlasic Range (Kamoun et al., 1997); Verbicaro Unit, Lucania and Calabria, Southern Italy (Climaco et al., 1997); Cetmi Melange, northwest 
Turkey (Beccaletto et al., 2005); North of Izmir, Turkey (Okay and Altiner, 2007) and other. Arabian shelf in the northern United Arab Emirates (Maurer et al., 2008); Norian of Dachstein Plateau, Northern Calcareous Alps, Upper Austria and Styria (Haas et al., 2010).

In eastern part of the Tethyan domain: Yushu region, Qinghai, Northwest China (He and Wang, 1990); Eastern Sulawesi, Indonesia (Martini et al., 1997); Seram, Indonesia (Martini et al., 2004); Sambosan Accretionary Complex, southern Kyushu, Japan (Chablais et al., 2010a).

Trochammina almtalensis Koehn-Zaninetti, 1969 (Pl. I, Figs 19-20). Section: Stoły pod Ciemniakiem (High-Tatric Unit; Fig. 4B); Biostratigraphical distribution: Anisian-Carnian (Bérczi-Makk, 1996a, b).

Geographical distribution: Almtal region, Austrian Alps (KoehnZaninetti, 1969); Trento, Northern Italy (Premoli Silva, 1971); Préalpes médianes rigides (Préalpes Romandes, Switzerland and the Chablais Préalpes, France) (Baud et al., 1971); Bosnia and Herzegovina (Brönnimann et al., 1973a, b); Choč nappe from the Tatra Mts. (Gaździcki and Zawidzka, 1973); Southern Poland (Gaździcki et al., 1975); Turkey, Austrian Alps and China (Zaninetti, 1976); West Carpathians (Salaj et al., 1983); Central and Southern Guizhou, China (He, 1984); Qinghai, Northewestern China (He and Wang, 1990); Oravita, Southern Carpathians, Romania (Bucur et al., 1997); Transdanubian Range (Oravecz-Scheffer, 1987); Bulgaria (Trifonova, 1992); Alsó Hill, Northern Hungary (Bérczi-Makk, 1996a, b).

Turriglommina mesotriasica (Kohen-Zaninetti, 1969) (P1. I, Fig. 24). Section: Hlúpy (Krížna Unit; Fig. 2B).

Biostratigraphical distribution: Early? Anisian-Carnian (Rettori, 1995), most often cited within the upper AnisianLadinian interval (Bucur et al., 1997).

Geographical distribution: Almtal region, Austrian Alps (Koehn-Zaninetti, 1969); Trento, Northern Italy (Premoli Silva, 1971); Choč nappe of the Tatra Mts., Poland (Gaździcki and Zawidzka, 1973); Caucasus (Efimova, 1974); Turkey, Austrian Alps and China (Zaninetti, 1976); Turkey (Dager, 1978); West Carpathian (Salaj et al., 1983); China (He, 1984; He and Cai, 1991); Transdanubian Range (Oravecz-Scheffer, 1987); Bulgaria (Trifonova, 1993); Eros Limestones, Hydra Island, Greece (Rettori et al., 1994); Tethyan domain (Rettori, 1995); NE of Oravita, Southern Carpathianhs, Rumania (Bucur et al., 1997); Karwendel range, Northern Calcareous Alps (Nittel, 2006); Arabian shelf in the northern United Arab Emirates (Maurer et al., 2008).

Turrispirillina prealpina Zaninetti and Boennimann in Zaninetti, Brönnimann and Baud, 1972b (Pl. I, Fig. 29).

Section: Stoły pod Ciemniakiem (High-Tatric Unit; Fig. 4B). Biostratigraphical distribution: Late Anisian-Norian (Rettori, 1995).

Geographical distribution: Préalpes médianes rigides, Switzerland and France (Zaninetti et al., 1972a, b); West Carpathians (Salaj et al., 1983); Bulgaria (Trifonova, 1993); Eros Limestones, Hydra Island, Greece (Rettori et al., 1994); Tethyan realm (Rettori, 1995).

In addition to described species, some other were determined: Agathamina sp., Gaudryina sp. (Żleb pod Czerwieniec section;
Fig. 5A), Trochammina sp., Tolypammina sp. (Skupniów Upłaz section; Fig. 2A), as well Aulotortus sp., Austrocolomia sp., Sigmoilina sp., Trochammina sp. and Palaeolituonella sp. from the Żleb pod Czerwoną Przełęcz section (Fig. 3).

\section{Calcareous algae}

In one sample from the High-Tatric Unit, rich assemblage of green algae there were present, comprising the following taxa (see Plate II):

\author{
cf. Diplopora annulatissima Pia, 1920 \\ Diplopora sp. \\ Kantia sp.
}

Oligoporella cf. dissita (Gümbel, 1872) Grgasović 1995

Oligoporella cf. minutula (Gümbel, 1872) Grgasović 1995

Oligoporella pilosa Pia, 1912, var. pilosa Pia ex Bystrický 1964

Oligoporella cf. praealpina Pia, 1920

Oligoporella sp.

Poncetella hexaster (Pia, 1912) Güvenć, 1979.

Section: Stoły pod Ciemniakiem (High-Tatric Unit; Fig4. B)

Biostratigraphical and geographical distribution: The assemblage containing species: Oligoporella dissita, O. minutula, O. pilosa, O. praealpina and Poncetella hexaster is very well known from Anisian deposits with a maximum in PelsonianLower Illyrian. This algae association was found in Europe only: Austria (Gümbel, 1872), Bosnia-Herzegovina (Pia, 1935; Herak, 1965), Bulgaria (Kotański and Čatalov, 1973), Croatia (Pia, 1912; 1920; 1925; Herak, 1965), Switzerland (Botteron, 1961), Greece (Herak, 1967), Italy (Senowbari-Daryan et al., 1993; Bassi and Fugagnoli, 2005), Poland (Kotański, 1986), Romania (Diaconu and Dragastan, 1969; Patrulius, 1970; Bleahu et al., 1972; Popa and Dragastan (1973); Dragastan and Grădinaru (1975); Dragastan et al., 1981; Strutinski et al., 1987; Bucur et al., 1994; Bucur, 1997), Slovakia (Pia, 1940; Bystrický, 1957; 1964; 1966; 1986; Flügel, 1982; Buček, 1989), Serbia (Pia, 1912; 1925; Herak, 1965; Pantić, 1970), Slovenia (Flügel et al., 1994), and Hungary (Budai et al., 1993, Piros, 2002).

A very interesting element of the assemblage consists of the probably presence of Diplopora annulatissima. This species was found in the same area as the previously mentioned assemblage, but also in Sicily (Senowbari-Daryan and Di Stefano, 2001), in Spain (Braga and Martin, 1987), and also in China (Bucur and Enos, 2001), the last occurrence belonging to the Eastern Asia palaeogeographical province. The presence of $D$. annulatissima could also have a biostratigraphical importance. The species is mainly known from Upper Anisian (Illyrian). Grgasović and Sokač (2003) mention that rare specimens of this species are also present in the Upper Pelsonian.

\section{STRATIGRAPHIC CONSIDERATIONS}

\section{High-Tatric Unit}

Many of the identified benthic foraminifera species have a relatively large stratigraphical range, covering almost all Triassic stages. However, some species are restricted to specific time intervals. The association recognized in sample from the upper part of the Stoły pod Ciemniakiem section, represented by a very characteristic Meandrospira dinarica (Pelsonian-Lower Illyrian) and Pilamminella semiplana species is undoubtedly of Anisian age, based on the occurrences of two index species for Anisian in Europe and in middle eastern Asia as well. 
Considering the whole assemblage containing calcareous algae Oligoporella species, characteristic for the Oligoporella pilosa-Physoporella pauciforata zone of Bystrický (1986), as well as presence of the foraminifera Meandrospira dinarica, and Diplopora annulatissima, which are characteristic for the Illyrian, the most probable age of the studied samples from the Stoły pod Ciemniakiem section is Lower Illyrian.

\section{Krížna Unit}

Numerous sections of the foraminifera species (Pilamminella semiplana (Kochansky-Devidéand Pantić), Glomospirella triphonensis Baud, Zaninetti and Broennimann and Nodosaria skyphica Efimova, from the limestones of the Lysanki section, as well as Hoyenella gr. sinensis (Ho), Agathammina sp. and Gaudryina sp. from Żleb pod Czerwieniec and Skoruśniak sections) undoubtedly indicate Anisian age of the studied Krížna Unit deposits. Identified foraminifera suggest probably early Anisian age due to the absence of index species of the Middle and Late Anisian (Pelsonian-Illyrian) Pilammina densa Pantić.

The dolostones of the Skupniów Upłaz and Hlúpy sections (Krížna Unit) comprise some characteristic foraminifera genera and species, which indicated the Ladinian age. The typical species for this time interval are: Turriglommina mesotriasica (KoehnZaninetti), Glomospirella gr. gemerica/kutani (Salaj), Aulotortus ex. gr. praegaschei (Koehn-Zaninetti, Trochammina cf. almtalensis Koehn-Zaninetti, Dentalina cf. zlambachensis Kristan-Tollmann, Agathammina cf. austroalpina Kristan-Tollmann and Tollman and Tolypammina sp. A Ladinian age is indicated by the Turriglomina mesotriasica - Glomospirella kuthani/gemerica - Aulotortus gaschei praegaschei assemblage presented in the dolostones of the Skupniów Upłaz and Hlúpy sections. The most representative species of this assemblage is T. mesotriasica in association with ovoid to spherical large Ammodiscidae referable to Glomospirella kuthani/gemerica which is of Ladinian-Carnian age. The presence of rare but very characteristic T. mesotriasica (KoehnZaninetti) together with species Glomospirella aff. gr. gemerica/ kutani (Salaj, Aulotortus ex. gr. praegaschei (Koehn-Zaninetti, Dentalina cf. zlambachensis Kristan-Tollmann, Agathammina austroalpina Kristan-Tollmann and Tollman, Trochammina sp. and Tolypammina sp. allows to refer this assemblage to the Ladinian, before the radiation and diversification of the Involutinidae family.

Dolostones of the Żleb pod Czerwoną Przełęcz section (Krížna Unit) comprise species which indicate Upper NorianRhaetian. The assemblage includes ?Triasina hantkeni Majzon which is the zone marker for many Upper Triassic successions. Triasina hantkeni range zone was first introduced by Salaj (1969) for the Rhaetian deposits of Western Carpathians. Salaj et al. (1988) redescribed the zone with the latest SevatianRhaetian range. The Late Norian (Sevatian) to Rhaetian age was corroborated by the occurrence of the ?Triasina hantkeni zone marker in many Upper Triassic successions, like in the Raetavicula contorta beds in the Northern Apennines (Ciarapica et al., 1987) and in the Briançonnais Domain in the Western Alps and in the Préalpes Médianes (Zaninetti et al., 1986). Other accompanying foraminifera in this zone are: Miliolipora cuvillieri Broennimann and Zaninetti, Aulotortus ex. gr. ?sinuosus Weynschenk, Hoyenella inconstans (Michalík,
Jendrejáková and Borza), Agathammina austroalpina Kristan-Tollmann and Tollman, Ophthalmidium cf. lucidum (Trifonova), Nodosaria nitidana Brand, Earlandia gracilis Pantic, E. tintinniformis (Mišik), Sigmoilina sp., Trochammina sp., Palaeolituonella sp. and Austrocolomia sp.

\section{FINAL REMARKS}

Most of recognized taxa of benthic foraminifera and calcareous algae are described for the first time from the AnisianNorian succession of High-Tatric and Krížna units in the Tatras. Unfortunatelly, only part of them belong to index fossils. Nevertheless, the horizons with index fossils can be useful as stratigraphic markers in the case of the High-Tatric Unit.

Acknowledgments. Authors are grateful to the managements of the Tatra National Parks (Poland) and Tatranský Narodný Park (Slovakia) for providing the permission for the fieldwork. Authors are indebted to two anonymous reviewers for their critical comments on the manuscript. The investigations were financed by MNiSW Grants PBN30703132/1609 (T.R) and 2P04D05229 (P.J) as well as by the Jagiellonian University (DS grant nr 809).

\section{REFERENCES}

Alexandrowicz, S., Szewczyk, E. 1981, Foraminifers from the Anisian marls of the Furkaska unit in the Western Tatra Mts., Poland. Biuletyn Instytutu Geologicznego, 331: 125-141.

Al-Juboury, A.J., Durovič, V. 1996, Supratidal origin of Carpathian Keuper dolostones. Mineralia Slovaca, 28: 12-20.

Al-Shaibani, S., Altiner, D., Brönnimann, P., Carter, D. J. \& Zaninetti, L. 1982, Triasina hantkeni Majzon, 1954 (Foraminifère), dans le Trias Supérieur de la Téthys (Europe et Asie). Archives des Sciences, Genève, 35 (2): 137-142.

Altiner, D., Zaninetti, L. 1981, Le Trias dans la région de Pinarbasi, Taurus oriental, Turquie: Unités Lithologiques, Micropaléontologie, Milieu de dépôt: Rivista Italiana di Paleontologia, 86 (4): 705-760.

Andrusov, D. 1959, Stratigraphie und Tektonik der mesozoichen Zone des Massives der Hohen Tatra. Geologický Sbornik Slovenskiej Akademie Vied, 10: 97-132.

Andrusov, D., Bystrický, J. \& Fusán, O. 1973, Outline of the structure of the West Carpathians. X Congress of Carpathian-Balkan Geological Association. Introductory Excursion Guidebook. Geologický Ústav Dionýza Štúra, Bratislava, p. 45.

Arnal, I., Calvet, F., Márquez, L., Márquez-Aliaga, A. \& Solé De Porta, N. 2002, La plataforma carbonatada epeírica (Formaciones Imón e Isábena) del Triásico superior del Noreste de la Península Ibérica. Acta Geologica Hispanica, 37 (4): 299-328.

Bac, M. 1971, Tectonics of the Bobrowiec Unit in the Western Tatra Mts. Acta Geologica Polonica, 21: 279-317.

Bac, M., Grochocka, K. 1965, La structure du pli de Czerwone Wierchy sur le versant est de la Valleé Kościeliska. Acta Geologica Polonica, 15: 331-354. 
Bac-Moszaszwili, M., Burchart, J., Głazek, J., Iwanow, A., Jaroszewski, W., Kotański, Z., Lefeld, J., Mastella, L., Ozimkowski, W., Roniewicz, P., Skupiński,A. \& WestwalewiczMogilska, E. 1979, Geological Map of the Polish Tatra,1:30 000. Wydawnictwa Geologiczne, Warszawa.

Baroz, F., Martini, R. \& Zaninetti, L. 1990, Un aspect de la Plate-forme carbonatee Triasique dans les Hellenides internes: le Chainon d'Oreokastro. Rivista Italiana Paleontologia e Stratigrafia, 96 (1): 21-38.

Bassi, D., Fugagnoli, A. 2005, Triassic dasycladalean algae from the dolomites (Northern Italy) : stratigraphic assessment. Revista Española de Micropaleontologia, 37 (1): 95-103.

Baud,A.,Zaninetti, L. \& Brönnimann, P. 1971, Les Foraminifères de L'Anisien (Trias Moyen) des Préalpes médianes rigides (Préalpes romandes, Suisse, et Préalpes du Chablais, France). Archives des Sciences, Genève, 24 (1): 73-95.

Beccaletto, L., Bartolini, A.-C., Martini, R., Hochuli, P. \& Kozur, H. 2005, Biostratigraphic data from the Çetmi Melange, northwest Turkey: Palaeogeographic and tectonic implications. Palaeogeography, Palaeoclimatology, Palaeoecology, 221: 215-244.

Bełka, Z., Gaździcki, A. 1976, Anisian foraminifers from the high-tatric series of the Tatra Mts. Acta Geologica Polonica, 26: 427-437.

Bérczi-Makk, A. 1996a, Foraminifera of the Triassic formations of Also Hill (northern Hungary). Part 1: Foraminifer assemblage of the Steinalm Limestone Formation. Acta Geologica Hungarica, 39 (2): 175-221.

Bérczi-Makk, A. 1996b, Foraminifera of the Triassic formations of Also Hill (northern Hungary). Part 2: Foraminifer assemblage of the Wetterstein Limestone Formation. Acta Geologica Hungarica, 39 (3): 223-309.

Bérczi-Makk, A. 1996c, Foraminifera of the Triassic formations of Also Hill (northern Hungary). Part 3: Foraminifer assemblage of the basinal facies. Acta Geologica Hungarica, 39 (4): 413-459.

Berra, F., Rettori, R. \& Bassi, D. 2005, Recovery of carbonate platform production in the Lombardy Basin during the Anisian: paleoecological significance and constrain on paleogeographic evolution. Facies, 50: 615-627.

Blau, J., Schmidt, Th. 1990, Zur Stratigraphie des Oberen Hauptdolomits (Nor) der Lienzer Dolomiten (Osttirol, Oesterreich). Geologisch-paläontologische Mitteilungen Innsbruck, 17: 1-23.

Blau, J., Wenzel, B., Senff, M. \& Lukas, V. 1995, Die Foraminiferen des Oberen Bundsandsteins (Roet) und des Unteren Muschelkalks (Germanische Trias: Skyth, Anis) in Nordhessen. Geologisch-paläontologische Mitteilungen Innsbruck, 20: 13-33.

Bleahu, M., Tomescu, C. \& Panin, Ş. 1972, Contribuţii la biostratigrafia depozitelor triasice din Platoul Vaşcău (Munţii Apuseni). Dări de Seamă ale şedinţelor Institutului de Geologie şi Geofizică, 58 (3): 6-25.

Botteron, G. 1961, Etude géologique de la région du Mont d'Or (Préalpes romandes). Eclogae Geologicae Helvetiae, 54 (1): 29-106.
Braga, J.C., Martin, J.M. 1987. Distribucion de los algas dasycladaceas en el Trias Alpujarride. Cuadernos Geologia Iberica, 11: 475-489.

Brönnimann, P., Cadet, J-P. \& Zaninetti, L. 1973a, Sul la Présence d'Involutina sinuosa pragsoides (Oberhauser) (Foraminifère) dans l'Anisien Supérieur probable de Bosnie-Herzègovine Méridionale, (Yougoslavie). Rivista Italiana di Paleontologia, 79 (3): 301-336.

Brönnimann, P., Cadet, J-P. \& Zaninetti, L. 1973b, Sur Quelques Foraminifères de 1'Anisien (Trias Moyen) de Bosnie-Herzègovine Méridionale, Yougoslavie. Rivista Italiana di Paleontologia, 79 (4): 461-478.

Brönnimann, P., Zaninetti, L., Bozorgnia, F., Dashti, G. R. \& Moshtaghian, A. 1971, Lithostratigraphy and Foraminifera of the Upper Triassic Nayband Formation, Iran. Revue de Micropaléontologie, 14 (5): 7-16.

Brönnimann, P., Zaninetti, L., Bozorgnia, F. \& Huber, H. 1972, Ammodiscids and ptychocladiids (Foraminiferida) from the Triassic Elika Formation, Nessa-Hassanakdar section, Central Alborz, Iran. Rivista Italiana di Paleontologia, 78 (1): 1-28.

Brönnimann, P., Zaninetti, L., Moshtaghian, A. \& Huber, H. 1973c, Foraminifera from the Sorkh Shale formation of the Tabas area, East-Central Iran. Rivista Italiana di Paleontologia, 79 (1): 1-32.

Bucur, I.I., Enos, P. 2001, Midle Triassic dasyclad algae from Guizhou, China. Micropaleontology, 47 (4): 317-338. http://dx.doi.org/10.2113/47.4.317

Bucur, I.I. 1997, Révision de la variété pilosa Pia ex Bystrický, 1964, de l'espèce Oligoporella pilosa Pia, 1912, une algue dasycladacée de l'Anisien. Revue de Paléobiologie, 16 (1): 181-186.

Bucur, I.I., Strutinski, C. \& Pop-Strătilă, D. 1994, Middle Triassic carbonate deposits and calcareous algae from the Sasca zone (Southern Carpathians, Romania). Facies, 30: 85-100.

Bucur, I.I., Strutinski, C. \& Paica, M. 1997, A new occurrence of Triassic deposits NE of Oravita (Southern Carpathians, Rumania) and its paleotectonic significance. Geologica Carpathica, 48 (1): 39-48.

Buček, S. 1989, Results of Dasycladacea algae studies in the Triassic rocks of the Male Karpaty Mts. Zbornik $z$ Paleontologickej Konferencie. Geologický Ústav Dionýza Štúra: 133-137 (In Slovakian).

Budai, T., Lelkes, G. \& Piros, O. 1993, Evolution of middle Triassic shallow marine carbonates in the Balaton Highland (Hungary). Acta Geologica Hungarica, 36 (1): 145-165.

Bystrický, J. 1957, Beitrag zur Kenntuis der Diploporen der Gemeriden-Trias. Geologicky Sbornik Slovenskiej Akademie Vied, 8 (2): 226-241.

Bystrický, J. 1964, Slovakian Karst. The stratigraphy and Dasycladacea of Mesozoic of Slovakian Karst. Ustřední Ústav Geologický, Bratislava, 204 p. (In Slovakian).

Bystrický, J. 1966, La stratigraphie et les dasycladacées du Trias moyen de la série de Drienok. Geologicky Sbornik Slovenskiej Akademie Vied, 12 (2): 241-257.

Bystrický, J. 1986, Stratigraphic ranging and zonation of Dasycladal Algae in the West Carpathians Mts., Triassic. Mineralia Slovaka, 18 (4): 289-321. 
Chablais, J., Martini, R., Samankassou, E., Onoue, T. \& Sano, H. 2010a, Microfacies and depositional setting of the Upper Triassic midoceanic atoll-type carbonates of the Sambosan Accretionary Complex (southern Kyushu, Japan). Facies, 56: 249-278. http://dx.doi.org/10.1007/s10347-009-0204-6

Chablais, J., Martini, R., Kobayashi, F., Stampfli, G. \& Onoue, T. 2011, Upper Triassic Foraminifers from Panthalassan carbonate buildups of Southwestern Japan and their paleobiogeographic implications. Micropaleontology, 57 (2): 93-124.

Chablais, J., Onoue, T. \& Martini, R. 2010b, Upper Triassic reef-limestone blocks of southwestern Japan: New data from a Panthalassan seamount. Palaeogeography, Palaeoclimatology, Palaeoecology, 293: 206-222. http://dx.doi.org/10.1016/j.palaeo.2010.05.022

Christodoulou, D., Tsaila-Monopolis, S. 1972, Contribution to the knowledge of the stratigraphy of Triassic in the eastern Hellenic zone. Bulletin of the Geological Society of Greece, 9: 101-118.

Ciarapica, G., Cirilli, S., Passeri, L., Trincianti, E. \& Zaninetti, L. 1987, "Anidriti di Burano" et "Formation du Monte Cetona" (Nouvelle Formation), biostratigraphie de deux series-types du Trias superieur dans l'Apennin septentrional. Revue de Paléobiologie, 6 (2): 341-409.

Ciarapica, G., Zaninetti, L. 1984, Aulotortus praegaschei (Koehn-Zaninetti, 1968): Revision Taxonomique et stratigraphique sur la base du materiel-type. Revue de Paléobiologie, 3 (1): 53-61.

Ciarapica, G., Zaninetti, L. 1985, Le cas de "Glomospirella FriedliAngulodiscus? Gaschei” (=Aulotortus friadli, Aulotortinae, Involutinidae, Foraminifère, Trias): Analyse structurale et révision taxonomique. Archives des Sciences, Genève, 38 (1): 71-86.

Climaco, A., Boni, M., Iannace, A. \& Zamparelli, V. 1997, Platform Margins, Microbial/Serpulids Bioconstructions and Slope-to-basin Sediments in the Upper Triassic of the 'Verbicaro Unit' (Lucania and Calabria, Southern Italy). Facies, 36: 37-56. http://dx.doi.org/10.1007/BF02536876

Dager, Z. 1975, Study on Involutina species occured in Taurus Mountain. Bulletin of the Geological Society of Turkey, 18: 151-156.

Dager, Z. 1978, Sur quelques Foraminiferes nouveaux du Trias de Kocaeli, Turquie. Notes du laboratoire de paleontologie de l'Universite de Geneve, 4: 21-24.

Di Bari, D., Baracca, A. 1998, Late Triassic (Carnian) Foraminifers of Northeastern Cortina D.Ampezzo (Tamarin, San Cassiano Fm., Dolomites, Italy). Annali dei Musei Civici di Rovereto, Sezione: Archeologia Storia Scienze Naturali, 12: 117-146.

Di Bari, D., Rettori, R. 1996, Morphological features of Triasina hantkeni Majzon, 1954 (Foraminiferida, Aulotortidae) and remarks on the test wall structure. Revue de Micropaléontologie, 39 (4): 305-313. http://dx.doi.org/10.1016/S0035-1598(96)90146-4

Diaconu, M., Dragastan, O. 1969, Triassic calcareous algae from the Apuseni Mountains (Romania). Review of Paleobotany and Palynology, 9: 63-101. http://dx.doi.org/10.1016/0034-6667(69)90013-X
Dragastan, O., Diaconu, M., Popa, E. \& Damian, R. 1981, Biostratigraphy of the Triassic formations in the East of the Pădurea Craiului Mountains. Dări de Seamă, Institutul de Geologie şi Geofizică, 67 (4): 29-61.

Dragastan, O., Grădinaru, E. 1975, Asupra unor alge, foraminifere, sphinctozoare şi microproblematice din Triasicul din carpaţii orientali şi Dobrogea de Nord. Studii şi Cercetări de Geologie, Geofizică, Geologie, seria Geologie, 20 (2): 247-254.

Dumont, T., Wieczorek, J. \& Bouillin, J.P. 1996, Inverted Mesozoic rift structures in the Polish Western Carpathians (High-Tatric units). Comparison with similar features in the Western Alps. Eclogae Geologica Helvetica, 89: 181-202.

Efimova, N. 1974, Triassic Foraminifera of the Northwest Caucasus and Cis-Caucasus. Voprosi Micropaleontologii, 17: 54-83.

Fijałkowska, A., Uchman, A. 1993. New data on palynology of the Triassic of the Polish Tatra Mts. Przeglad Geologiczny, 41: 373-375.

Flügel, E. 1982, Microfacies analysis of limestones. SpringerVerlag, Berlin, 633 p.

http://dx.doi.org/10.1007/978-3-642-68423-4

Flügel, E., Ramovš, A., \& Bucur, I.I. 1994, Middle Triassic (Anisian) Limestones from Bled, Northwestern Slovenia: Microfacies and Microfossils. Geologija, 36: 157-181.

Gaillot, J., Vachard, D. 2007, The Khuff Formation (Middle East) and time-equivalents in Turkey and South China: biostratigraphy from Capitanian to Changhsingian times (Permian), new foraminiferal taxa, and palaeogeographical implications. Coloquios de Paleontología, 57: 37-223.

Gale, L., Rettori, R., Martini, R., Smuc, A., Kolar-Jurkovsek, T. \& Rozic, B. 2011, Duostominidae (Foraminifera, Robertinida) from the Upper Triassic beds of the Slovenian basin (Southern Alps, Slovenia). Rivista Italiana di Paleontologia e Stratigrafia, 117 (3): 375-397.

Gaździcki, A. 1974, Rhaetian microfacies, stratigraphy and facial development in the Tatra Mts. Acta Geologica Polonica, 24 (1): 17-96.

Gaździcki, A. 1983, Foraminifers and biostratigraphy of Upper Triassic and Lower Jurassic of the Slovakian and Polish Carpathians. Palaeontologia Polonica, 44: 109-169.

Gaździcki, A., Kozur, H., Mock, R. \& Trammer, J. 1978, Triassic microfossils from the Korytnica Limestones at Liptovská Osada (Slovakia, ĆSSR) and Their Stratigraphic Significance. Acta Palaeontologica Polonica, 23 (3): 351-373.

Gaździcki, A., Lipiec, M. 1995, Anisian foraminifers from the Ogarle-Opalone unit (High-Tatric Series, Polish Tatra Mts, Southern Poland). Przegląd Geologiczny, 43: 385-387.

Gaździcki, A., Michalík, J. 1980, Uppermost Triassic sequences of the Choč nappe (Hronic) in the West Carpathians of Slovakia and Poland. Acta Geologica Polonica, 30 (1): 61-76.

Gaździcki,A., Trammer, J. \& Zawidzka, K. 1975, Foraminifers from the Muschelkalk of southern Poland. Acta Geologica Polonica, 25 (2): 285-298.

Gaździcki, A., Zawidzka, K. 1973, Triassic foraminifer assemblages in the Choč nappe of the Tatra Mts. Acta Geologica Polonica, 23 (3): 483-490. 
Głazek, J., Trammer, J. \& Zawidzka, K. 1973, The Alpine microfacies with Glomospira densa (Pantić) in the Muschelkalk of Poland and some related paleogeographical and geotectonic problems. Acta Geologica Polonica, 23 (3): 463-482.

Goetel, W. 1917, Die rhätische Stufe und der unterste Lias der subtatrischen Zone in der Tatra. Bulletin International de l'Académie des Sciences Mathématiques et Naturelles, Série A, Sciences Mathématiques, Année 1916: 1-222.

Goetel, W., Sokołowski, S. 1929, La structure tectonique de la zone subtatrique aux environs de Zakopane. Rocznik Polskiego Towarzystwa Geologicznego, 6: 235-301.

Grgasović, T. 1995, Revision of genera Physoporella, Steinmann and Oligoporella, Pia (Dasycladales, green algae). In Abstracts of Sixth International Symposium on Fossil Algae and Carbonate Platforms, Ankara, Turkey, p. 15.

Grgasović, T., Sokač, B. 2003, Review of the fossil dasycladalean associations in the Triassic of Croatia. Acta Micropaleontologica Sinica. 20 (1): 75-79.

Groves, R.J., Altiner, D. \& Rettori, R. 2005, Extinction, survival, and recovery of Lagenide foraminifers in the Permian-Triassic boundary interval, central Taurides, Turkey. Journal of Paleontology, 79: 1-38. http://dx.doi.org/10.1666/0022-3360(2005)79[1:ESAROL]2.0.CO;2

Groves, J., Rettori, R., Payne, J., Boyce, M. \& Altiner, D. 2007, End-Permian mass extinction of Lagenide foraminifers in the southern Alps (northern Italy). Journal of Paleontology, 81: 415-434. http://dx.doi.org/10.1666/05123.1

Guzik, K., Kotański, Z. 1963, La tectonique de la zone subtatriqe de Zakopane. Acta Geologia Polonica, 13: 387-412.

Gümbel, C.W. 1872, Die sogennanten Nulliporen (Lithothamnium und Dactylopora) und ihre Betheiligung an der Zusammensetzung der kalkgesteine. Zweiter Theil: Die Nulliporen des Thierreichs (Dactyloporideae) nebst Nachtrag zum ersten Theile. Abhandlungen der Bayerischen Akademie der Wissenschaften, MathematischPhysikalische Klasse 11 (1): 231-289.

Haas, J., Piros, O., Budai, T., Görög, Á., Mandl, G. \& Lobitzer, H. 2010, Transition Between the Massive Reef-Backreef and Cyclic Lagoon Facies of the Dachstein Limestone in the Southern Part of the Dachstein Plateau, Northern Calcareous Alps, Upper Austria and Styria. Abhandlungen der Geologischen Bundesanstalt, 65: 35-56.

He, Y. 1984, Middle Triassic foraminifera from Central and Southern Guizhou, China. Acta Palaeontologica Sinica, 23 (4): 420-431.

He, Y. 1988, Early and Middle Triassic foraminifera from Jiangsu and Anhui Provinces, China. Acta Micropalaeontologica Sinica, 5 (1): 85-92.

He, Y. 1993, Triassic foraminifera from Northeast Sichuan and South Shaanxi, China. Acta Palaeontologica Sinica, 32 (2): 184-186.

He, Y., Cai, L.Q. 1991, Middle Triassic Foraminifera from Tiandong Depression, Baise Basin, Guangxi, China. Acta Palaeontologica Sinica, 30: 212-230.
He, Y., Wang, L. 1990, Triassic foraminifera from Yushu region, Qinghai. Devonian-Triassic Stratigraphy and Palaeontology from Yushu region of Qinghai, China, Part I. Nanjing University Press, Nanjing, p: 59-96.

Herak, M. 1965, Comparative study of some Triassic Dasycladaceae in Yougoslavia. Geoloski vjesnik, 18 (1): 3-34.

Herak, M. 1967, Mesozoische Kalkalgen der Insel Chios (Griechenland). Neues Jahbruch für Geologie und Paläontologie Abhandlungen, 129 (1): 97-104.

Ho, Y. 1959, Triassic foraminifera from the Chialingkiang Limestone of South Szechuan. Acta Palaeontologica Sinica, 7: 387-418.

Jaglarz, P. 2010, Facies and sedimentary environment of the carbonate-dominated Carpathian Keuper from the Tatricum domain: results from the Dolina Smytnia valley (Tatra Mts, Southern Poland). Annales Societatis Geologorum Poloniae, 80: 147-161.

Jaglarz, P., Rychliński, T. 2010, Remarks on nomenclature of the Triassic carbonate rocks from the Tatra Mts. Przeglad Geologiczny, 58: 327-334.

Jaglarz, P., Szulc, J. 2003, Middle Triassic evolution of the Tatricum sedimentary basin: an attempt of sequence stratigraphy to the Wierchowa Unit in the Polish Tatra Mts. Annales Societatis Geologorum Poloniae, 73: 169-182.

Jaglarz, P., Uchman, A. 2010, A hypersaline ichnoassemblage from the Middle Triassic carbonate ramp of the Tatricum domain in the Tatra Mountains, Southern Poland. Palaeogeography, Palaeoclimatology, Palaeoecology, 292: 71-81. http://dx.doi.org/10.1016/j.palaeo.2010.03.027

Jurewicz, E. 2005. Geodynamic evolution of the Tatra Mts. and the Pieniny Klippen Belt (Western Carpathians): problems and comments. Acta Geologica Polonica, 55: 295-338.

Kamoun, F., Martini, R., Peybernes, B. \& Zaninetti, L. 1994, Caractérisation micropaléontologique du "Rhétien" dans 1'Axe Nord-Sud (Tunisie Centrale): Comparaison avec le Rhétien de la dorsale et de la Plate-forme Saharienne. Rivista Italiana Paleontologia e Stratigrafia, 100 (3): 365-382.

Kamoun, F., Peybernes, B., Martini, R., Zaninetti, L., Vila, J.-M., Trigui, A. \& Rigane, A. 1997, Associations de foraminifères benthiques dans les séquences de dépôt du Trias moyen?-supérieur de 1'Atlas Tunisien central et méridional. Geobios, 31 (6): 703-714.

http://dx.doi.org/10.1016/S0016-6995(98)80104-6

Kobayashi, F. 1996, Middle Triassic (Anisian) foraminifers from the Kaizawa Formation, southern Kanto Mountains, Japan. Transactions and Proceedings of the Palaeontological Society of Japan - New Series, 183: 528-539.

Kobayashi, F. 2008, Lithology and foraminifers of Triassic limestones in the Maizuru Terrane of the Yakuno area, Kyoto Prefecture, Japan. Humans and Nature, 19: 61-65.

Kobayashi, F., Martini, R., Rettori, R., Zaninetti, L., Ratanasthien, B., Saegusa, H. \& Nakaya, H. 2006, Triassic foraminifers of the Lampang Group (Northern Thailand). Journal of Asian Earth Sciences, 27: 312-325. http://dx.doi.org/10.1016/j.jseaes.2005.04.003 
Kobayashi, F., Martini, R. \& Zaninetti, L. 2005, Anisian foraminifers from allochthonous limestones of the Tanoura formation (Kurosegawa Terrane, West Kyushu, Japan). Geobios, 38: 752-763.

http://dx.doi.org/10.1016/j.geobios.2004.06.004

Koehn-Zaninetti, L. 1969, Les Foraminiferes du Trias de la Region de L'Almtal (Haute-Autriche). Jahrbuch der Geologischen Bundesanstalt, Sonderband, 14: 1-155.

Koehn-Zaninetti, L., Brönnimann, P. 1968, Triasina oberhauseri, n. sp., un Foraminifère nouveau de la Dolomie principale des Alpes Calcaires septentrionales (Autriche). Institut de Paléontologie, Université de Genève: 1-8.

Kotański, Z. 1956a, High-tatric Campilian in the Tatra Mts. Acta Geologica Polonica, 6: 65-73.

Kotański, Z. 1956b, Stratigraphic and palaeogeographic problems in the High-Tatric Keuper.. Acta Geologica Polonica, 6: 273-286.

Kotański, Z. 1958, Stratigraphic and paleogeographic position of the Triassic in the Bielanskie Tatra Mts. Bulletin de l'Academie Polonaise des Sciences, Sèrie des Sciences Chimiques Geologiques et Geographiques, 8 (2): 559-565.

Kotański, Z. 1959a, High-Tatric Triassic. Biuletyn Instytutu Geologicznego, 149: 143-157.

Kotański, Z. 1959b, Stratigraphy, sedimentology and paleogeography of the high-tatric Triassic in the Tatra Mts. Acta Geologica Polonica, 9: 113-145.

Kotański, Z. 1961, Tectogénese et reconstitution de la paléogeografie de la zone hauttatrique dans les Tatras. Acta Geologica Polonica, 11: 186-476.

Kotański, Z. 1963, Stratigraphie et lithologie du Trias Subtatrique de la region de Zakopane. Acta Geologica Polonica, 13: 317-385.

Kotański, Z. 1965, La structure géologique de la chaîne subtatrique entre la vallée de Mała Łąka et la vallée Kościeliska dans les Tatras Occidentales. Acta Geologica Polonica, 15: 257-330.

Kotański, Z. 1967, Paleontological basis of the Triassic stratigraphy in the Tatra Mts. Geologicky Zbornik (Geologica Carpathica), 17: 277-283.

Kotański, Z. 1973, Microfacies characteristic and stratigraphical division of carbonate Triassic rocks from the Zakopane IG 1 borehole. Biuletyn Instytutu Geologicznego, 265: 205-228.

Kotański, Z. 1979a, On the Triassic of the Tatra Mts. Przegląd Geologiczny, 27: 369-377.

Kotański, Z. 1979b, The position of the Tara Mountains in the Western Carpathians. Przegląd Geologiczny, 27: 359-369.

Kotański, Z., 1986, Class Chlorophyta. In Geology of Poland v. III, Atlas of guide and characteristic fossils, part 2a: Mesozoic, Triassic. (Malinowska, L., Ed.), Wydawnictwa Geologiczne, Warszawa, p. 177-184.

Kotański, Z., Čatalov, A. 1973, Triassic dasycladaceae from central Balkan and fore-Balkan, Bulgaria. Acta Palaeontologica Polonica, 18 (2): 187-210.
Kozur, H. 1991, The evolution of the Meliata-Hallstatt ocean and its significance for early evolution of the Eastern Alps and Western Carpathians. Palaeogeography, Palaeoclimatology, Palaeoecology, 8: 109-135.

http://dx.doi.org/10.1016/0031-0182(91)90132-B

Kristan-Tollmann, E. 1962, Stratigraphisch wertvolle Foraminiferen aus Obertrias- und Liaskalken der voralpinen fazies bei Wien. Erdoel-Zeitschrift, 4: 3-8.

Kristan-Tollmann, E. 1964, Die Foraminiferen aus den rhätisschen Zlambachemergeln der Fischerwiese bei Aussee im Salzkammegut. Jahrbuch der Geologischen Bundesanstalt, 10: 1-189.

Kristan-Tollmann, E. 1984, Trias-Foraminiferen von Kumaun im Himalaya. Mitteilungen der Österreichischen Geologischen Gesellschaft, 77: 263-329.

Kristan-Tollmann, E., Tollmann, A. 1963, Das mittelostalpine Rhät-Standardprofil aus dem Stangalm-Mesozoikum (Kärnten). Sonderdrück aus Mitteilungen der Österreichischen Geologischen Gesellschaft, Wien, 56 (2): 539-589.

Lefeld, J. 1958, Dadocrinus grundeyi Langenhahn (Crinoidea) from the High-Tatric Middle Triassic in the Tatra Mountains (Poland). Acta Paleontologica Polonica, 3: 59-74.

Martini, R., Cirilli, S., Saurer, C., Abate, B, Ferruzza, G. \& Lo Cicero, G. 2007, Depositional environment and biofacies characterization of the Triassic (Carnian to Rhaetian) carbonate succession of Punta Bassano (Marettimo Island, Sicily). Facies, 53 (3): 389-400. http://dx.doi.org/10.1007/s10347-007-0115-3

Martini, R., Peybernès, B. \& Moix, P. 2009, Late Triassic Foraminifera in Reefal Limestones of SW Cyprus. Journal of Foraminiferal Research, 39 (3); 218-230.

http://dx.doi.org/10.2113/gsjfr.39.3.218

Martini, R., Peybernès, B., Zaninetti, L. \& Frèchengues, M. 1996, Découverte de Foraminifères dans les intervalles Transgressifs de deux Séquences de Dépot Anisiennes (Muschelkalk) du bassin de la Weser (Hesse, Allemagne du Nord). Geobios, 24 (5): 505-511.

http://dx.doi.org/10.1016/S0016-6995(96)80021-0

Martini, R., Vachard, D., Zaninetti, L., Cirilli, S., Cornée, J-J., Lathuiliére, B. \& Villeneuve, M. 1997, Sedimentology, stratigraphy, and micropaleontology of the Upper Triassic reefal series in Eastern Sulawesi (Indonesia). Palaeogeography, Palaeoclimatology, Palaeoecology, 128: 157-174.

http://dx.doi.org/10.1016/S0031-0182(97)81128-5

Martini, R., Zaninetti,L., Lathuiliere, B., Cirilli, S., Cornee, J.J. \& Villeneuve, M. 2004, Upper Triassic carbonate deposits of Seram (Indonesia): palaeogeographic and geodynamic implications. Palaeogeography, Palaeoclimatology, Palaeoecology, 206: 75-102.

http://dx.doi.org/10.1016/j.palaeo.2003.12.020

Maurer, F., Rettori, R., Martini, R. 2008, Triassic stratigraphy, facies and evolution of the Arabian shelf in the northern United Arab Emirates. International Journal of Earth Science, 97: 765-784.

http://dx.doi.org/10.1007/s00531-007-0194-y 
Michalík, J. 1993, Mesozoic tensional basins in the AlpineCarpathian shelf. Acta Geologica Hungarica, 36: 395-403.

Michalík, J. 1994, Notes on the paleogeography and paleotectonics of the Western Carpathian area during the Mesozoic. Mitteilungen der Österreichischen Geologischen Gesellschaft, 86: 101-110.

Michalík, J., Gaździcki, A. 1980, Is the Stražov nappe present in the Tatra Mts.? Przegląd Geologiczny, 28: 616-619.

Michalík, J., Jendrejáková, O. \& Borza, K. 1979, Some new foraminifera-species of the Fatra-formation (Uppermost Triassic) in the West Carpathians. Geologický zbornik Geologica Carpathica, 30 (1): 61-91.

Muttoni, G., Rettori, R. 1993, New biostratigraphic data on the Triassic of the Marathovouno Hillock area (Chios Island, Greece). Rivista Italiana Paleontologia e Stratigrafia, 99, 4: 461-472.

Niedźwiedzki, R., Salamon, M.A. 2006, Triassic crinoids from the Tatra Mountains and their stratigraphic significance (Poland). Geologica Carpathica, 57: 69-77.

Nittel,P.2006, Beitragezur Stratigraphie und Mikropalaontologie der Mitteltrias der Innsbrucker Nordkette (Nordliche Kalkalpen, Austria). Geo. Alp., 3: 93-145.

Okay, A., Altiner, D. 2007, A Condensed Mesozoic Succession North of Izmir: A Fragment of the AnatolideTauride Platform in the Bornova Flysch Zone. Turkish Journal of Earth Sciences, 16: 257-279.

Oravecz-Scheffer, A. 1987, Triassic Foraminifers of the Transdanubian Central Range. Geologica Hungarica, Seria Palaeontologica, 50: 3-331.

Pantić, S. 1964, Pilammina densa n. gen., n. sp. and other Ammodiscidae from the Middle Triassic in the Crmnica (Montenegro). Geološki Vjesnik, Zagreb, 18 (1): 189-193.

Pantić, S. 1970, Caractéristiques micropaléontologiques de la colonne triasique de l'anticlinal de Zdrelo (Serbie orientale). Zavod geol., geofiz. Istraz., Vesnik (Geol.), ser. A, 28: 463-495.

Pantić, S. 1972, Aeolisaccus amplimuralis n. sp. and Aeolisaccus gracilis n. sp. from the Middle Triassic southeastern Dinarides. Buletin Museum d'Histoire Naturelle, Serie A, 27: 211-221 (in Croatian).

Pantić, S., Rampnoux, J.P. 1972, Concerning the Triassic in the Yugoslavian Inner Dinarids (Southern Serbia, Eastern Montenegro): microfacies, microfaunas, an attempt to give a paleogeographic reconstitution. Mitteilungen der Gesellschaft der Geologie- und Bergbaustudenten in Österreich, 21: 311-326.

Pantić-Prodanović, S., Radosević, B. 1977, Geological section of Scythian and Anisian Srages in the Jelovica River Valley (Southeastern Serbia). Buletin Museum d'Histoire Naturelle, Serie A, 32: 75-95.

Passendorfer, E. 1961. Évolution paléogéographique des Tatras. Rocznik Polskiego Towarzystwa Geologicznego, 30: 351-387.

Patrulius, D. 1970, Inventar sumar al algelor dasycladaceae triasice din Carpaţii româneşti. Dări de seamă ale şedinţelor, Institutul de Geologie şi Geofizică, 55 (3): 187-195.
Peybernès, B., Kamoun, F., Ben Youssef, M., Trigut, A., Ghanmi, M., Zarbout, M. \& Frechengues, M. 1993, Sequence stratigraphy and micropaleontology of the Triassic series from the southern part of Tunisia. Journal of African Earth Sciences (and the Middle East), 17 (3): 293-305. http://dx.doi.org/10.1016/0899-5362(93)90074-Z

Peybernès, B., Martini, R. \& Zaninetti, L. 1991, Les Foraminifères Benthiques du Trias carbonaté (Ladinien-? Carnien et Rhétien) de Corse. Geobios, 24 (6): 683-696. http://dx.doi.org/10.1016/S0016-6995(06)80297-4

Pia, J. 1912, Neue Studien über die triadischen Siphoneae Verticillatae. Beiträge zur Paläontologie und Geologie Österreich-Ungarns und des Orients. Mitteilungen des pläontologischen und geologischen Institutes der Universität Wien, 25: 25-81.

Pia, J. 1920, Die Siphoneae Verticillatae vom Karbonbis zur Kreide. Abhandltmgen der Zoologisch-Botanischen Gesellschaft in Wien, 11 (2): 1-263.

Pia, J. 1925, Die Diploporen der Trias von Süddalmatien. Sitzungsberichten der Akademie der Wissenschaften in Wien. Mathematisch-Naturwissenschaftlichen Klasse, Abteilung I, 133 (7-8): 329-345.

Pia, J. 1935, Die Diploporen der anisischen Stufe Bosniens. Annales Géologiques de la Péninsule Balkanique, 12 (2): 190-246.

Pia, J. 1940, Wirtellalgen (Dasycladaceen) aus anisischen Kalken des Szilicei fennsik in Nordungarn. Abhandlungen aus dem Mineralogisch-Geologischen Institut der St. TiszaUniversität in Debrecen, 18: 1-7.

Piotrowski, J. 1965, Le Trias moyen et la tectonique du massif de Kominy Tylkowe. Acta Geologica Polonica, 15: 355-392.

Piros, O. 2002, Anisian to Carnian carbonate platform facies and dasycladacean biostratigraphy of the Aggtelek Mts, Northeastern Hungary. Acta Geologica Hungarica, 45 (2): 119-151. http://dx.doi.org/10.1556/AGeol.45.2002.2.1

Popa, E. Dragastan, O. 1973, Anisian-Ladinian calcareous algae and foraminifera from the eastern part of Pădurea Craiului (Apuseni Mountains). Sudii şi cercetări de geologie, geofizică, geografie, seria Geologie, 18 (2): 425-442.

Premoli Silva, J. 1971, Foraminiferi anisici della regione giudicariense (Trento). Rivista Italiana di Paleontologia e Stratigrafia, 77 (3): 303-374.

Rabowski, F. 1931, Guide partiel de l'excursion de la Société géologique de Pologne. Rocznik Polskiego Towarzystwa Geologicznego, 7: 108-119.

Rettori, R. 1994, Replacement name Hoyenella, gen. n. (Triassic Foraminiferida, Miliolina) for Glomospira sinensis Ho, 1959. Bollettino della Società Paleontologica Italiana, 33 (3): 341-343.

Rettori, R. 1995, Foraminiferi del Trias inferiore e medio della Tetide: revisione tassonomica, stratigrafia ed interpretazione filogenetica. Publications du Département de Géologie et Paléontologie, Université de Genève, 18: 147 p.

Rettori, R., Angiolini, L. \& Muttoni, G. 1994, Lower and Middle Triassic foraminifera from the Eros Limestone, Hydra Island, Greece. Journal of Micropaleontology, 13: 25-46. http://dx.doi.org/10.1144/jm.13.1.25 
Rychliński, T. 2008, Facies development and sedimentary environments of the Carpathian Keuper deposits from the Tatra Mountains, Poland and Slovakia. Annales Societatis Geologorum Poloniae, 78: 1-18.

Rychliński, T., Jaglarz, P. 2010, Sedimentation of the Triassic sequence in Tatricum and Fatricum basins (Tatra Mts.). In Nauka a zarzadzanie obszarem Tatr i ich otoczeniem, tom I, Nauki o Ziemi. (Kotarba, A., Ed.), Wydawnictwa Tatrzańskiego Parku Narodowego, p. 131-136.

Rychliński, T., Jaglarz, P., Bucur, I.I., Hagdorn, H. \& Ivanova, D. 2008, New palaeontological data from the Triassic of the Tatra Mts. In Abstracts of $9^{\text {th }}$ Paleontological Conference (Pisera, A., Bitner, M.A., Halamski, A.T., Eds.), Warszawa, Poland, p. 80-82.

Rychliński, T., Szulc, J. 2005, Facies and sedimentary environments of the Upper Scythian-Carnian succession from the Belanské Tatra Mts., Slovakia. Annales Societatis Geologorum Poloniae, 75: 155-169.

Salaj, J., Biely, A., Bystrický, J. 1967, Trias-Foraminiferen in der Westkarpaten. Geologicke Prace, 42: 119-136.

Salaj, J., Borza, K., Samuel, O. 1983. Triassic Foraminifers of the West Carpathians. Geologický ústav Dionýza Štúra, Bratislava, 213 p.

Scourtsis-Coroneou, V., Trifonova, E. \& Tselepidis, V. 1992, Foraminifera Sequences from the Anisisan (Hallstatt Facies) of the Epidaurus Area, Peloponnesus (Greece). Benthos'90: Studies in Benthic Foraminifera: 361-367.

Senowbari-Daryan, B. 2003, Micropaleontology of Limestone Beds within the Shotori Dolomite (Triassic) of Kuh-e Nayband, Tabas Area, East-Central Iran. Facies, 48: 115126. http://dx.doi.org/10.1007/BF02667534

Senowbari-Daryan, B., Di Stefano, P. 2001, Middle Triassic Dasycladales in Sicily: Evidence of an Anisian?-Ladinian carbonate platform. Acta Geologica Hungarica, 44 (1): 95-109.

Senowbari-Daryan, B., Rashidi, K. \& Torabi, H. 2010, Foraminifera and their associations of a possibly Rhaetian section of the Nayband Formation in central Iran, northeast of Esfahan. Facies, 56: 567-596. http://dx.doi.org/10.1007/s10347-010-0221-5

Senowbari-Daryan, B., Zühlke, R., Bechstädt, T. \& Flügel, E. 1993, Anisian (Middle Triassic) buildups of the Northern Dolomites (Italy): the recovery of reefs communities after the Permian/Triassic crisis. Facies, 28: 181-256. http://dx.doi.org/10.1007/BF02539736

Sokołowski, S. 1948, Les Tatry Bielskie. La géologie de leurs Versants Meridionaux. Prace Państwowego Instytutu Geologicznego, 4: 1-47.

Strutinski, C., Bucur, I.I., Nicu, M., Pop-Strătilă, D. \& Török, I. 1987, New data on the stratigraphy and tectonic position of the triassik deposits from Sasca Montană (Banat hills, Romania). Sudia UBB Geologia, 32 (2): 61-69.

Trifonova, E. 1992, Taxonomy of Bulgarian Triassic foraminifera. I. Families Psammosphaeridae to Nodosinellidae. Geologica Balcanica, 22 (1):3-46.
Trifonova, E. 1993, Taxonomy of Bulgarian Triassic foraminifera. II. Families Endothyriidae to Ophthalmidiidae. Geologica Balcanica, 23 (2): 19-62.

Trifonova, E. 1994, Taxonomy of Bulgarian Triassic Foraminifera. III. Families Spiroloculiniidae to Oberhausereliidae. Geologica Balcanica, 24 (2): 21-70.

Turnau-Morawska, M. 1953, Tatra Keuper, its petrography and sedimentology. Acta Geologica Polonica, 3: 33-102 (in Polish).

Uchman, A. 2004, Tatras, their sedimentary rocks and sedimentological studies. In Materiaty konferencyjne, Polska Konferencja Sedymentologiczna POKOS (Kędzierski, M., Leszczyński, L., Uchman, A., Eds), Kraków, Poland, p. 5-21 (in Polish).

Uhlig, V. 1897, Die Geologie des Tatragebirges. I. Einleitung und stratigraphischer Theil. Denkschriften der Akademie der Wissenchaften, Wien, MathematischNaturwissenschaftliche Klasse 64: 643-684.

Vachard, D., Colin, J-P., Hochuli, P. \& Rosell, J. 1990, Biostratigraphie: Foraminifères, palynoflore et ostracodes du Rhetien de Bac Grillera (Pyrenees Orientales Espagnoles). Geobios, 23 (5): 521-537. http://dx.doi.org/10.1016/0016-6995(90)80024-A

Villeneuve, M., Cornee, J.-J., Martini, R., Zaninetti, L., Rehault, J.-P., Burhanudin, S. \& Malod, J. 1994, Upper Triassic shallow water limestones in the Sinta Ridge (Banda Sea, Indonesia). Geo-Marine Letters, 14: 29-35. http://dx.doi.org/10.1007/BF01204468

Wieczorek, J. 2000, Mesozoic evolution of the Tatra Mountains (Carpathians). Mitteilungen der Gesellschaft der Geologie und Bergbaustudenten in Wien, 44: 241-262.

Zamparelli, V., Iannace, A., Rettori, R. 1995, Upper Triassic foraminifers (Ammodiscidae and Aulotortidae) from the scifarello formation, s. donato unit (Northern Calabria, Italy). Revue de Paléobiologie, 14, 2: 399-409.

Zaninetti, L. 1976, Les foraminifères du Trias. Essai de synthèse et correlation entre les domaines mésogéens européen et asiatique. Rivista Italiana di Paleontologia e Stratigrafia, 82: 1-258.

Zaninetti, L., Altiner, D., Dağer, Z. \& Ducret, B. 1982, Les milioliporidae (Foraminiferes) dans le Trias superieur a facies recifal du Taurus, Turquie. II: Microfaunes associees. Revue de Paléobiologie, 1 (2): 105-139.

Zaninetti, L., Broennimann, P. \& Baud, A. 1972a, Essai de zonation d'après les Foraminifères dans l'Anisien moyen et supérieur des Préalpes médianes rigides (Préalpes romandes, Suisse, et Préalpes du Chablais, France). Eclogae Geologicae Helvetiae, 65 (2): 343-353.

Zaninetti, L., Broennimann, P. \& Baud, A. 1972b, Microfacies particuliers et foraminifères nouveaux de l'Anisien supérieur de la coupe du Rothorn (Préalpes médianes rigides, Diemtigtal, Suisse). Mitteilungen Gesellschaft Geolgisches Bergbaustudieren, 21: 465-498.

Zaninetti, L., Broennimann, P., Bozorgnia, F. \& Huber, H. 1972c, Étude litologique et micropaléontologique de la Formation d'Elika dans la coupe d'Aruh, Alborz central, Iran septentrional. Archives des Sciences, Genève, 25 (2): 215-249. 
Zaninetti, L., Martini, R. \& Dumont, T. 1992, Triassic Foraminifers from Sites 761 and 764, Wombat Plateau, Northwest Australia. Proceedings of the Ocean Drilling Program, Scientific Results, 122: 427-436.

Zaninetti, L., Rettori, R. \& Martini, R., 1994a, Aulotortus? eotriasicus n. sp., un nuovo foraminifero del Trias medio (Anisico) delle Dinaridi ed Ellenidi. Bollettino Società Paleontologica Italiana, 33: 43-49.
Zaninetti, L., Rettori, R. \& Martini, R. 1994b, Paulbronnimanninae Rettori \& Zaninetti, 1993 (Foraminiferida, Ammodiscidae) and other Anisian foraminifers from the Piz da Peres section (Valdaora-Olang, Pusteria Valley, Dolomites, NE Italy). Rivista Italiana di Paleontologia e Stratigrafia, 100 (3): 339-350. 
Plate 1. Determined foraminifera from High-Tatric and Krížna units (Anisian-Norian) (Scale bar: A - x 80; B - x160).

Fig. 1. Aulotortus ex.gr. ?sinuosus Weynschenk, 1956 (Żleb pod Czerwoną Przełęcz, Krížna Unit, x80).

Figs 2-4. Aulotortus ex. gr. praegaschei (Koehn-Zaninetti, 1969) (2 - Skupniów Upłaz, Krížna Unit, x80; 3, 4 - Żleb pod Czerwoną Przełęcz, Krížna Unit, x80).

Figs 5-6. Glomospirella vulgaris Ho, 1959 (Stoły pod Ciemniakiem, High-Tatric Unit, x80).

Figs 7-9. Pilamminella semiplana (Kochansky-Devide \& Pantić, 1966) (Stoły pod Ciemniakem, High-Tatric Unit, x80).

Fig. 10. Miliolipora cuvillieri Brönnimann \& Zaninetti in Brönnimann, Zaninetti, Bozorgnia, Dashti \& Moshtaghian, 1971 (Żleb pod Czerwoną Przełęcz, Krížna Unit, x80).

Fig. 11. Diplotremina ?astrofimbriata Kristan-Tollmann, 1960 (Kominiarski Wierch, High-Tatric Unit, x160).

Figs 12-13. Meandrospira dinarica Kochansky-Devidé \& Pantić, 1966 (Stoły pod Ciemniakiem, High-Tatric Unit, x160).

Figs 14-15. Hoyenella inconstans (Michalík, Jendrejáková \& Borza, 1979) (Żleb pod Czerwoną Przełęcz, Krížna Unit, x160).

Fig. 16. Agathammina? iranica Zaninetti, Brönnimann, Bozorgnia \& Huber, 1972c (Stoły pod Ciemniakiem, High-Tatric Unit, x160).

Figs 17-18. Agathammina austroalpina Kristan-Tollmann \& Tollman, 1963 (Skupniów Upłaz, Żleb pod Czerwoną Przełęcz, Krížna Unit, $\mathrm{x} 160$ ).

Figs 19-20. Trochammina almtalensis Koehn-Zaninetti, 1969 (19 - Stoły pod Ciemniakiem, HighTatric Unit); (20 - Skupniów Upłaz, Krížna Unit, x160).

Fig. 21. Undetermined foraminifer (Żleb pod Czerwieniec, Krížna Unit, x160).

Fig. 22. Earlandia gracilis Pantić, 1972 (Żleb pod Czerwoną Przełęcz, Krížna Unit, x80).

Fig. 23. Earlandia tintinniformis (Mišik, 1971) (Żleb pod Czerwoną Przełęcz, Skupniów Upłaz, Krížna Unit, x160).

Fig. 24. Turriglommina mesotriasica (Kohen-Zaninetti, 1969) (Hlúpy, Krížna Unit, x160).

Figs 25-26. Nodosaria skyphica Efimova, 1974 (Stoły pod Ciemniakiem, Kominiarski Wierch, High-Tatric Unit, x160).

Fig. 27. Nodosaria nitidana Brand, 1937 (Żleb pod Czerwoną Przełęcz, Krížna Unit, x160).

Fig. 28. Dentalina cf. zlambachensis Kristan-Tollmann, 1964 (Hlúpy, Krížna Unit, x160).

Fig. 29. Turrispirillina prealpina Zaninetti \& Boennimann in Zaninetti, Brönnimann \& Baud, 1972b (Stoły pod Ciemniakiem, High-Tatric Unit, x160).

Fig. 30. ?Triasina hantkeni Majzon, 1954, emend. Koehn-Zaninetti, 1968 (Żleb pod Czerwoną Przełęcz, Krížna Unit, x80). 
PLATE I
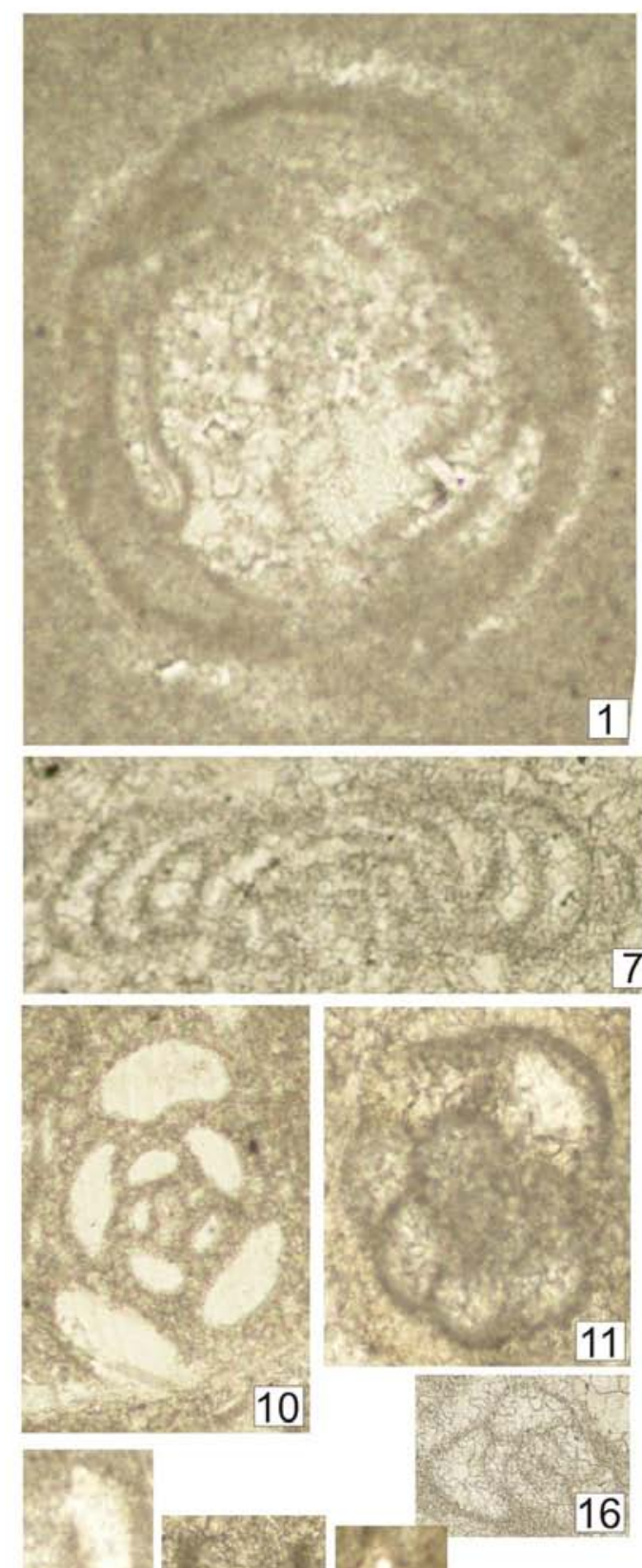

1
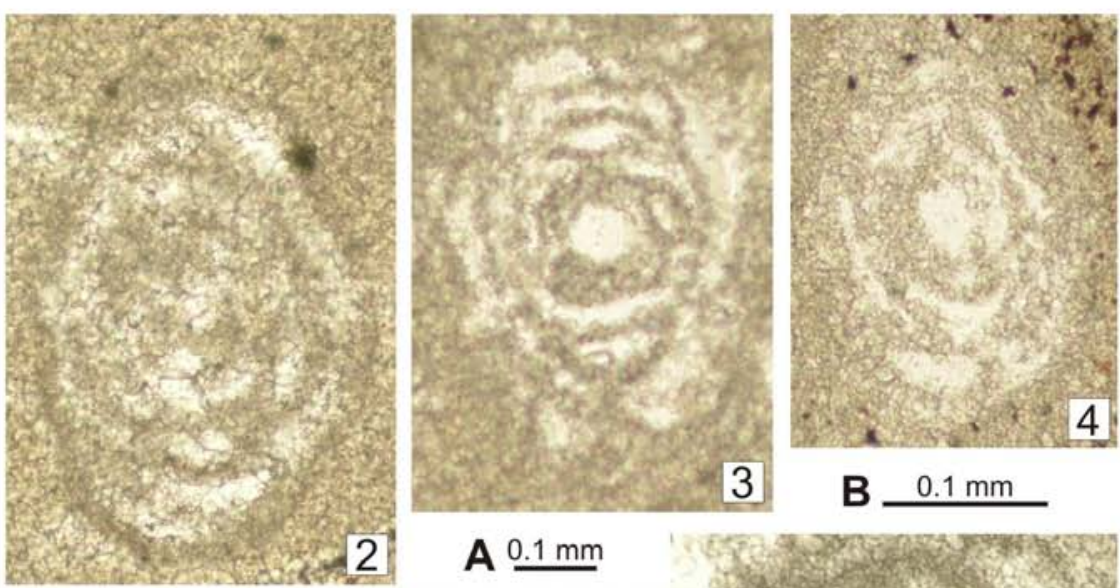

\section{A $\underline{0.1 \mathrm{~mm}}$}

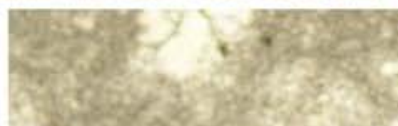

ats.

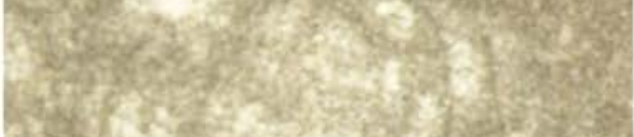

\section{(3)}

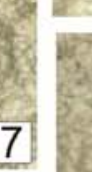

5

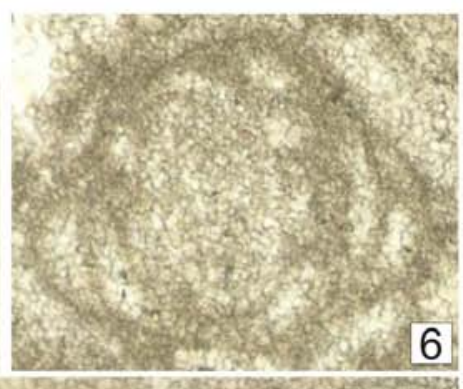

8
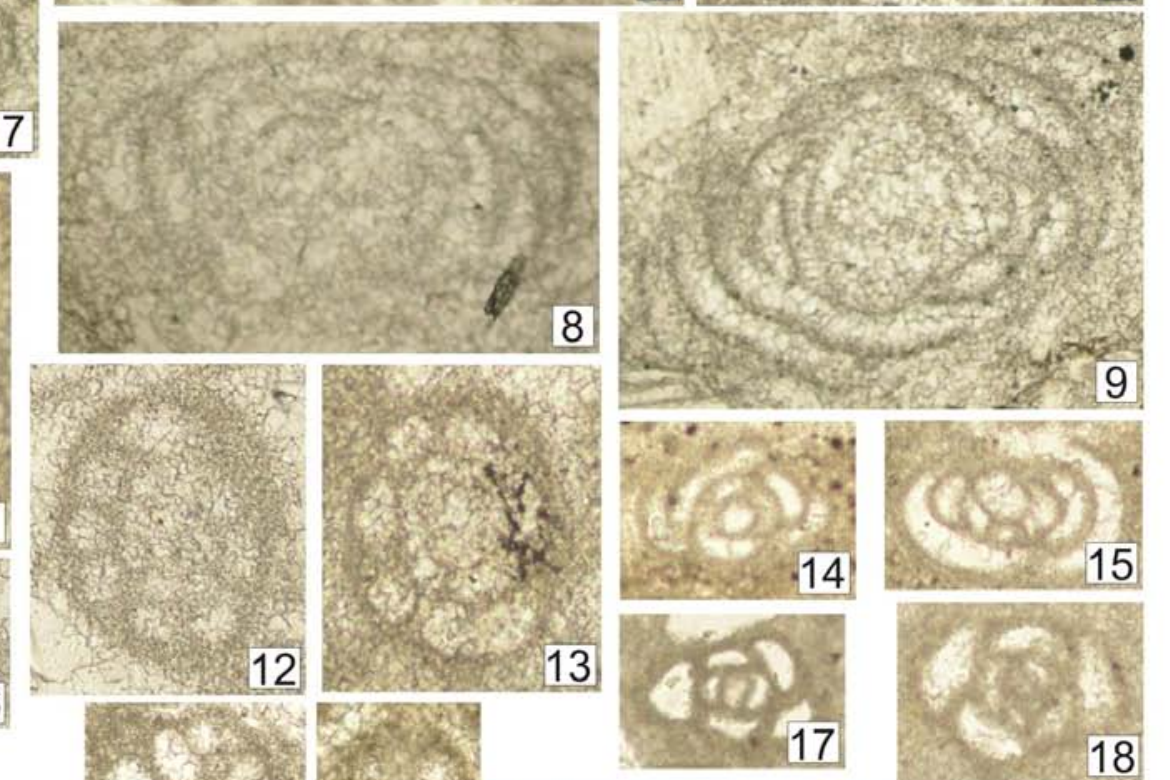

$$
\begin{array}{r}
7 \\
7 \\
9 \\
15 \\
18 \\
18 \\
\hline
\end{array}
$$

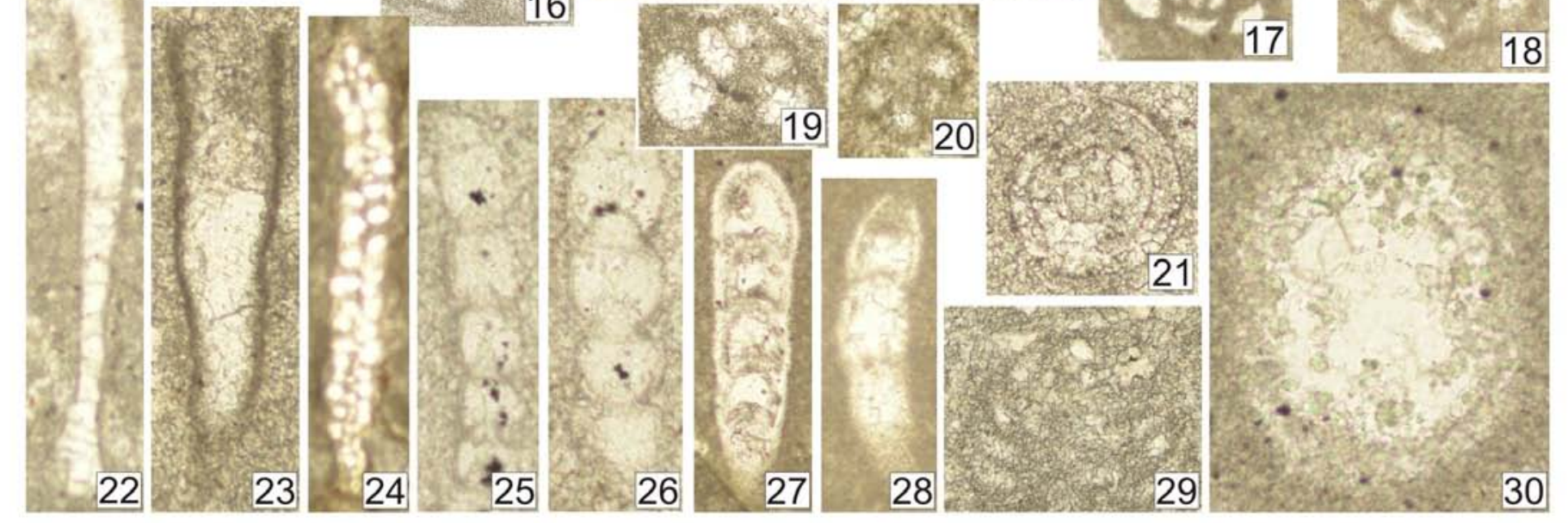


Plate 2. Determined calcareous algae from the Stoły pod Ciemniakiem section (High-Tatric Unit; see Fig. 4B).

Fig. 1. cf. Diplopora annulatissima PIA. Oblique section.

Fig. 2. Diplopora sp. Transverse section.

Fig. 3. Oligoporella cf. praealpina PIA. Oblique section.

Fig. 4. Kantia sp. Transverse section.

Fig. 5. Oligoporella sp. Oblique section.

Figs 6-8. Oligoporella cf. dissita (Gümbel). 6 - oblique-tangential (left) and transverse (upper right) sections; 7 - longitudinal-oblique section; 8 - tangential-oblique section.

Fig. 9. Oligoporella cf. minutula (Gümbel). Transverse section.

Fig. 10. Poncetella hexaster (Pia). Transverse section.

Figs 11-12. Oligoporella pilosa pilosa Pia. Transverse sections.

Fig. 13. Oligoporella sp. Transverse section. 

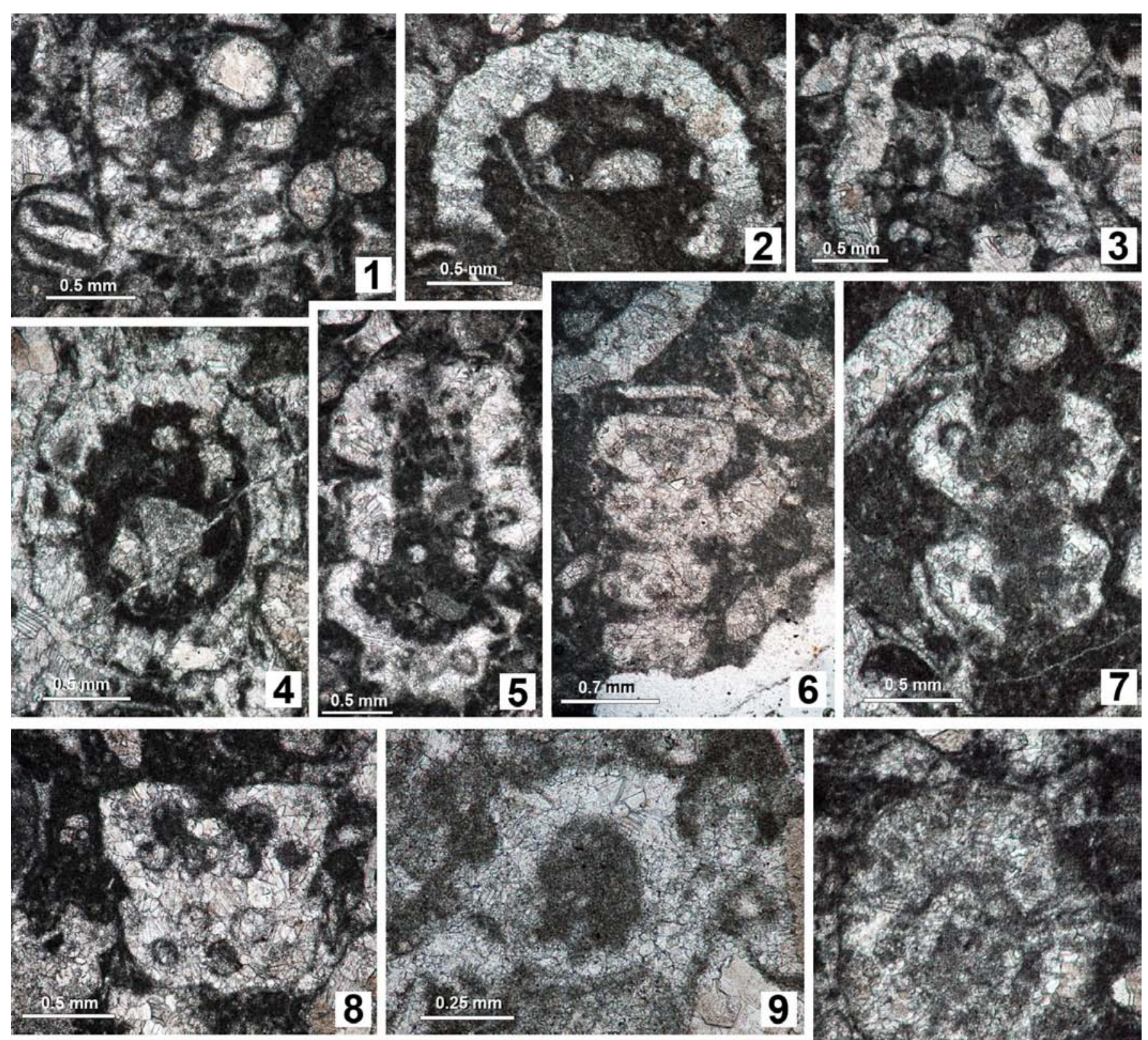

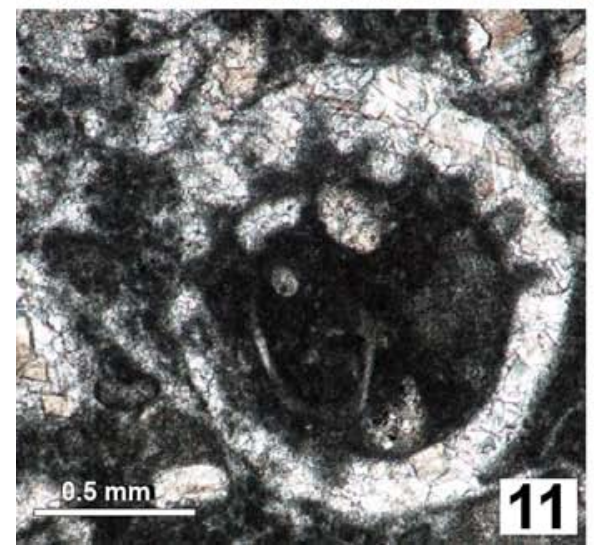

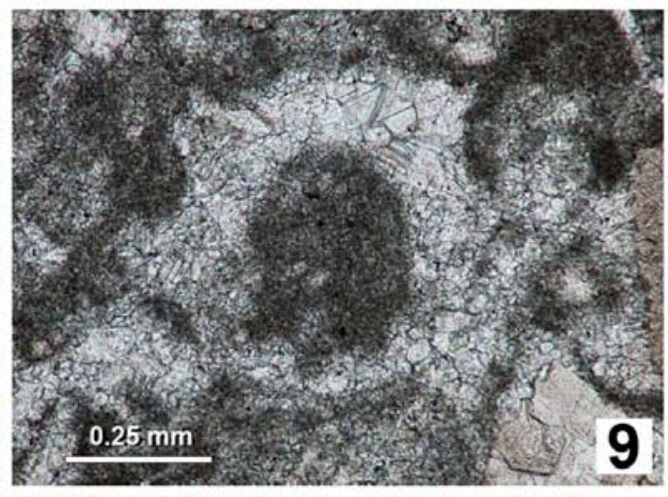

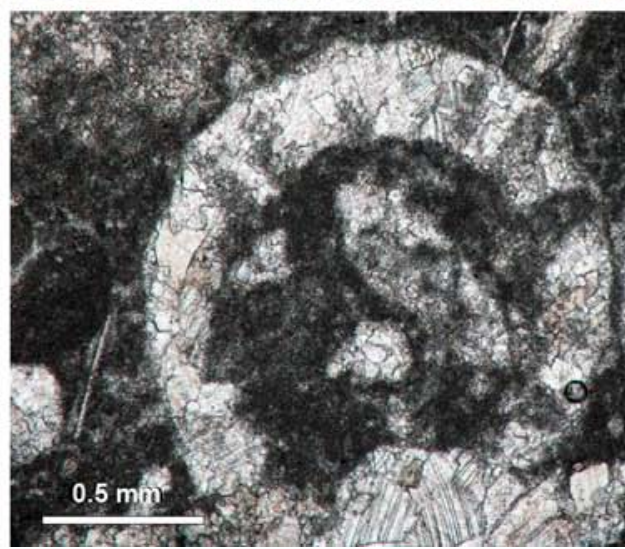

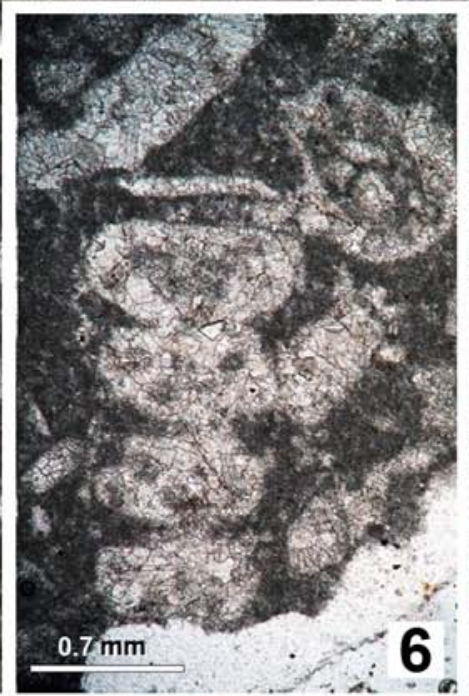

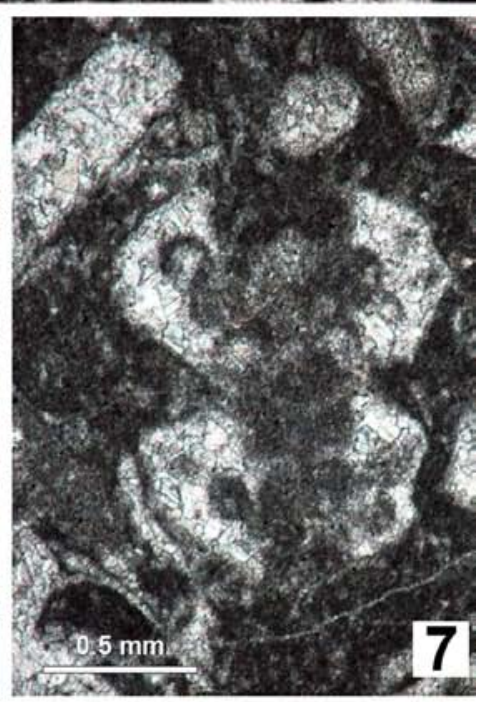

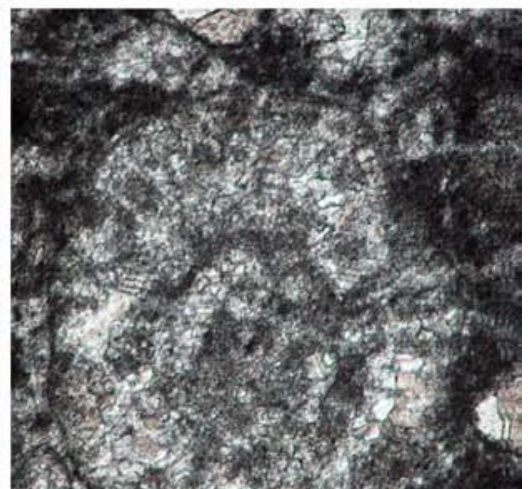

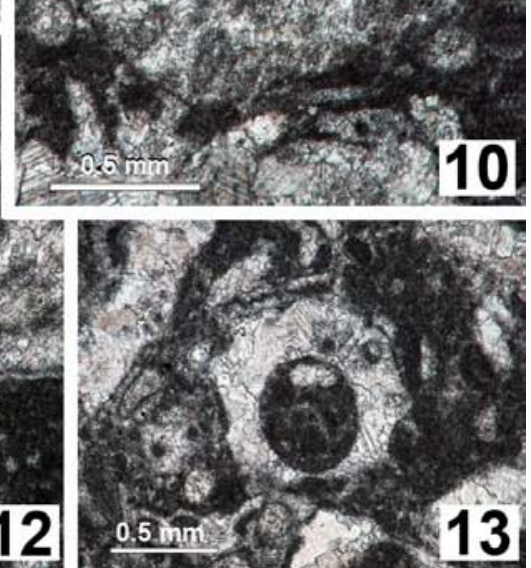

